\title{
Representações de História em Jovens da Escola Básica e da Universidade: um Estudo sobre Pensamento Histórico e Identidade.
}

\author{
Representations of history in young people from the basic school and \\ university: a study on historical thought and identity.
}

\author{
Márcia Elisa Teté Ramos ${ }^{1}$ \\ Ronaldo Cardoso Alves ${ }^{2}$
}

RESUMO

\begin{abstract}
O artigo tem como objetivo estudar o confronto de representações sociais entre jovens do Ensino Médio do período noturno de uma escola pública de Londrina - PR e da graduação em História da Universidade Estadual de Londrina, por meio da análise de ideias históricas que remetem a aspectos de sua orientação temporal e formação identitária. A pesquisa pautou-se por utilizar elementos de inspiração etnográfica e questionários qualitativos, com o fim de conhecer os perfis socioeconômicos e culturais, bem como aspectos importantes relacionados à formação do pensamento histórico dos grupos pesquisados.
\end{abstract}

Palavras-chave: Juventude. Representações. Pensamento Histórico.

\section{ABSTRACT}

This article aims to study the confrontation of social representations among high school youth the nighttime of a public school in Londrina - PR and graduated in history from the Universidade Estadual de Londrina, through the analysis of historical ideas that refer to aspects of temporal orientation and identity formation. The research was characterized by using ethnographic-inspired elements and qualitative questionnairesin order to meet the socio-economic and cultural backgrounds, as well as important aspects related to the formation of historical thinking of the groups surveyed.

Keyword: Youth. Representations. Thought History.

1 Docente do curso de História e do Mestrado Profissional em Ensino de História da Universidade Estadual de Maringá (UEM) e do programa de pós-graduação em História Social,linha de pesquisa História e Ensino da Universidade Estadual de Londrina (UEL).

2 Docente da UNESP - Assis, coordenador do PIBID História, docente do programa de pós-graduação em História Social, linha de pesquisa História e Ensino da Universidade Estadual de Londrina (UEL). 
"Professor, impressionante como os estudantes atuais são diferentes da minha época. Querem tudo rápido. Não têm paciência para nada. Realmente muita coisa mudou na escola de lá para cá.”

A frase citada na epígrafe comumente nos remete ao choque de gerações no contexto escolar. Poder-se-ia pensar que foi dita em um contexto de professores experientes na escola de educação básica referindo-se a seus estudantes, muitos anos mais novos. O lugar? Poderse-ia pensar que tenha sido dita em um curso de extensão, destes que, de vez em quando, é oferecido na universidade para formação continuada de professores com muitos anos na caminhada docente, ou mesmo em uma reunião de conselho de classe ou de reuniões com a coordenação pedagógica no cotidiano das escolas.

Mas, não...

De forma surpreendente a frase foi dita não por um, mas por alguns estudantes de graduação em História, participantes do PIBID (Programa Institucional de Bolsa de Iniciação à Docência) da UNESP/Assis, ao analisarem as diferentes maneiras com as quais os estudantes do Ensino Médio se relacionam com o espaço escolar e tudo que o compõe: professores, funcionários, material didático, espaço físico, etc.

Desse contexto apresentado suscita-se a seguinte questão: o que leva estudantes da licenciatura, com cerca de vinte anos de idade, a verificarem mudança tão drástica entre seu período como estudante do Ensino Médio e dos atuais estudantes que acompanham em seus estágios da licenciatura, quando tais momentos são separados por apenas três, quatro, quando muito, cinco anos?

Esta, dentre outras questões, norteou uma pesquisa desenvolvida no Laboratório de Ensino de História da Universidade Estadual de Londrina, nos anos de 2011 a 2014, realizada junto aos graduandos do $4^{\circ}$ ano do curso de História. Investigação que tinha como objetivo inicial verificar o que pensam os jovens estudantes do Ensino Médio a respeito de si mesmos, da História e de seu ensino. Entretanto, no decorrer do trabalho percebeu-se a necessidade de promover, em concomitância, uma investigação com os próprios "pesquisadores" estudantes da graduação com a finalidade de contrapor suas representações com aquelas trazidas pelos estudantes do Ensino Médio.

A ampliação do trabalho permitiria, assim, verificar como os estudantes de ambos os grupos, com distância etária tão pequena, porém vinculados a etapas diferentes da escolarização, identificam-se com a categoria "juventude". Será que ambos se entendem como jovens? Como se relacionam com a temporalidade? A História, seu ensino e aprendizagem são importantes? Por quê? 
Destarte, o presente artigo tem como objetivo estudar o confronto de representações sociais entre jovens do Ensino Médio e da graduação em História, por meio da análise de ideias históricas que remetem a aspectos de sua orientação temporal e formação identitária. Para a consecução dessa intenção, a pesquisa pautou-se por utilizar instrumentos de inspiração etnográfica e questionários qualitativos, com o fim de conhecer os perfis socioeconômicos e culturais, bem como aspectos importantes relacionados à formação do pensamento histórico dos grupos pesquisados.

\section{Os Grupos Pesquisados}

Costuma-se pensar que os chamados "adolescentes" ${ }^{3}$ não se preocupam com o futuro, pois vivem num eterno presentismo ao não se envolverem com política como deveriam e, quando resolvem se envolver, o fazem com superficialidade, via redes sociais. Tal concepção se repete quando se entende que a juventude não se interessa por História ou pelo ensino de História.

Nos últimos anos, a temática da juventude adquiriu visibilidade crescente no Brasil, pois o peso relativo dessa categoria etária na população teve sensível aumento. Os brasileiros de 15 a 24 anos somam hoje 34 milhões, representando cerca de $20 \%$ da população. Pode-se dizer que os jovens ocupam o centro de questões que comovem o país, tanto no que diz respeito aos problemas gerados pelo agravamento das desigualdades, como no que se refere à esperança de novos rumos. É possível a firmar que os jovens são os brasileiros mais afetados pelo tipo de desenvolvimento econômico e social enfrentado por um país, ou seja, talvez os que mais sofrem com a exclusão.

A presente pesquisa teve como inspiração os caminhos tomados pelo "Projeto Juventude"4, um amplo programa de estudos, pesquisas, discussões e seminários em vários Estados, promovido pelo Instituto Cidadania, entre agosto de 2003 e maio de 2004. A redação final do documento resultado do Projeto foi aperfeiçoada com observações críticas oferecidas por movimentos de juventude, organizações não-governamentais (ONGs), especialistas,

3 As palavras derivadas de "adolescente" estarão entre aspas no decorrer do texto, pois o próprio termo vem se consolidando ao longo do tempo - passa a ser empregado no Brasil a partir de aproximadamente 1950 -, conformando-se a uma significação pejorativa em relação a este sujeito.

4 No Projeto Juventude, 300 entrevistadores colheram depoimentos de 3.501 jovens (de 15 a 24 anos), em 198 municípios brasileiros de todos os Estados. Partiam de blocos temáticos para a investigação, com 158 perguntas: perfil sociodemográfico e situação familiar; percepções da condição juvenil, da escola, do mundo do trabalho remunerado e de políticas voltadas para a juventude; valores e referências que norteiam suas escolhas; inserção em espaços de participação, percepções da política, dos direitos de cidadania e das relações de gênero; fruição cultural e lazer; influências epreferências da mídia; percepções sobre sexualidade e AIDS, sobre drogas lícitas e ilícitas; violência e políticas de segurança (VENTURINI, 2005, p. 23-24). 
parlamentares e gestores públicos que contribuíram nas várias etapas do Projeto. Em sua concepção, a denominação "jovens" se refere aos sujeitos que se encontram na faixa etária compreendida entre 15 e 24 anos, portanto, atinente aos grupos pesquisados em nossa investigação: graduandos e estudantes do Ensino Médio.

O primeiro grupo pesquisado é composto por 89 graduandos do curso de História da UEL, dos períodos matutino e noturno (com exceção do ano de 2012, com alunos apenas do matutino), enquanto o segundo grupo, formado por estudantes do Ensino Médio uma escola pública de Londrina - PR, somava 424 pessoas.

\section{Aspectos teórico-metodológicos}

\section{a) Da pesquisa qualitativa: a etnografia educacional}

Para compor um perfil dos grupos pesquisados e investigar o pensamento desses estudantes da licenciatura e do Ensino Médio utilizou-se um instrumento de pesquisa simples, em forma de questionário, do qual serão mencionados alguns resultados adiante, além de elementos de inspiração etnográfica. A etnografia educacional possibilita que se promova a observação participante, na qual o pesquisador interage com os sujeitos da pesquisa. Além disso, anotações de campo são feitas com o objetivo de suscitar uma descrição densa5 do espaço pesquisado, bem como a dinâmica de seus respectivos sujeitos (GEERTZ, 2012, p. 15).

Espaço no qual a heterogeneidade de pessoas, grupos e identidades se apresenta, a escola é lugar profícuo de investigação das práticas cotidianas, das ações que apresentam as formas pelas quais ocorrem os embates referentes às questões estruturais do tempo histórico: o pensamento político; as manifestações culturais referenciadas na tradição familiar, na religiosidade; as desigualdades socioeconômicas; as relações público-privadas que influenciam os indivíduos e grupos na sociedade globalizada, etc. A etnografia educacional, nesse sentido, possibilita a interpretação das representações que demonstram a heterogeneidade de pensamentos e ações no espaço escolar, as quais refletem o encontro com o que estudantes e professores trazem de seu cotidiano.

5 Entende-se como "descrição densa" o relato feito pelo etnógrafo que visa caracterizar a "multiplicidade de estruturas conceptuais complexas, muitas delas sobrepostas ou amarradas umas às outras, que são simultaneamente estranhas, irregulares e inexplícitas, e que ele tem que, de alguma forma, primeiro apreender e depois apresentar.” (GEERTZ, 2012, p.20) 
Em um momento histórico no Brasil em que professores e estudantes têm defendido o direito à liberdade de expressão e pensamento no espaço escolar, dada a assunção de narrativas e representações conservadoras de movimentos que visam judicializar e asfixiar a escola, retirando-lhe seu caráter democrático de educar os indivíduos para a convivência em sociedade, respeitar a alteridade de pensamento e o espaço público, ou seja, promover cidadania, a etnografia educacional se apresenta como referencial metodológico importante. Assim consideramos porque compreende estudantes e professores como mútuos construtores do pensamento, desconstruindo, portanto, uma visão estereotipada e conservadora criada por esses movimentos que entendem crianças, adolescentes e jovens como tabulas rasas do saber, meros depositários e reprodutores do conhecimento prescrito e imposto por professores dominadores que, no entender desses grupos, visam pautar a orientação temporal e a identidade de crianças, ou seja, a consciência histórica.

A escola não pode ser separada do processo histórico, pois as diferentes representações que nela se apresentam se relacionam, intrinsecamente, às discussões presentes no cotidiano, na vivência histórica de seus participantes, a qual é influenciada por narrativas oriundas da família, do ambiente social (clubes, instituições religiosas, sociais, culturais, etc), das diferentes mídias (internet, televisão, rádio, etc), dentre outras. Tal heterogeneidade narrativa é representada em sala de aula por meio de discursos e ações, e se encontram/confrontam com narrativas cientificamente concebidas, oriundas dos professores, materiais didáticos, recursos didático-tecnológicos, etc. Nesse sentido, EZPELETA e ROCKWELL (1989, p. 26-27) propõem que: "A única forma de dar conta do heterogêneo [...] é a de reconhecê-lo como produto de uma construção histórica. As atividades que se observam atualmente começam a ganhar sentido quando são referidas a esta dimensão histórica".

Pesquisar o conhecimento prévio dos estudantes acerca de um tema a ser discutido, interpretar as diferentes representações suscitadas por esses mesmos estudantes após a discussão proposta, estabelecer categorias analíticas que permitam o acurado estudo da origem de tais representações permitem aos pesquisadores da Didática da História, por exemplo, a compreenderem em que medida a construção do conhecimento histórico escolar, por meio de seu repertório epistemológico próprio de sua ciência, tem contribuído para a reflexão dos discentes e docentes a respeito das narrativas de orientação no tempo presente.

Percebe-se, portanto, que a escola é lugar de heterogeneidade de representações, a qual, é composta por professores com seu repertório (in)formacional, que podem reproduzir ou problematizar prescrições do Estado ou narrativas do cotidiano extraescolar. Movimento similar ocorre com os estudantes, pois enquanto parte deles pode se contentar com a superficialidade de narrativas prescritivas dos universos intra e extraescolares, outros podem construir dinâmico processo reflexivo em que os objetos de estudo oriundos das diferentes disciplinas são problematizados. Nesse sentido, não há como separar a escola da vida, do cotidiano, pois 
Quando tentamos reconstruir o 'especificamente' escolar, recortamos de fato, a unidade de vida cotidiana dos sujeitos engajados na escola. A partir destes sujeitos [...] organizam-se numerosas atividades de seu mundo, sem que correspondam necessariamente a domínios isolados ou a delimitações institucionais. A partir deles, estabelece-se [...] a hierarquia e a congruência relativa das atividades cotidianas. Num âmbito como o escolar, os sujeitos costumam integrar práticas e saberes que provêm de outros âmbitos e excluir de sua prática cotidiana elementos que pertencem ao domínio escolar. (EZPELETA; ROCKWELL, 1989, p. 26-27).

Entender que as narrativas escolares são suficientes para nortear totalmente as ações no tempo de crianças, adolescentes e jovens é, no mínimo, desconhecer a dinâmica do espaço escolar, por meio de uma visão estereotipada, até mesmo "míope", que não condiz com o cotidiano de estudantes, professores e demais atores dessa instituição, pois

[...] O que é cotidiano para uma pessoa, nem sempre o é para outras. Num mundo de contrastes como o da escola, começa-se a distinguir assim as múltiplas realidades concretas que vários sujeitos podem identificar $\mathrm{e}$ viver como 'escola' e a compreender que ela é objetivamente distinta de acordo com o lugar em que é vivenciada. (EZPELETA; ROCKWELL, 1989, p. 22)

Nessa perspectiva, conforme André (1995) orienta, a etnografia educacional possibilita uma investigação qualificada como interpretativa, não limitada somente ao empirismo. É o caso da atuação dos estudantes-estagiários que se comprometeram a apreender as significações elaboradas pelos alunos do Ensino Médio nas aulas de história. Tal observação possibilitou a descrição de discursos simbólicos e/ou identitários, hábitos e elementos da racionalidade histórica, apresentados em sala de aula. Esta fase mais descritiva do que explicativa, compreendeu anotações sistemáticas e atenção ao que se passava, considerando atores (alunos), lugar (sala de aula) e atos (práticas relativas ao livro didático, às metodologias e recursos didáticos, participação na aula, reações, etc.). Esta primeira fase de observação de campo serviu para obtenção de elementos que subsidiaram a elaboração do instrumento de 
pesquisa com vistas a investigar os conhecimentos prévios/tácitos dos alunos do Ensino Médio, em forma de questionário.

Assim, a realização da pesquisa se deu no contato direto dos pesquisadores (graduandos) com o objeto/sujeito de pesquisa (alunos do Ensino Médio, bem como com a utilização de técnicas emprestadas da pesquisa etnográfica, no sentido de documentar ações, interações e representações presentes no cotidiano da prática escolar (ANDRÉ, 1995, p.41), o que significou articular o empirismo da coleta de dados com a participação efetiva no campo de investigação.

Inicialmente, um instrumento de pesquisa visou traçar um perfil dos graduandos do curso de licenciatura em História com vistas a coletar elementos que contribuíssem para a análise de seus conhecimentos prévios/tácitos, apresenta questões de matiz socioeconômica (relativas à idade, série em que estuda, sexo, estado civil, número de filhos, renda familiar, trabalho, etc.), bem como relacionadas ao universo cultural como, por exemplo, periodicidade de acesso à Internet, páginas que costuma acessar, média de horas semanais em que se utiliza da rede, músicas/filmes/livros/programas de TV prediletos e, ainda, questões que diziam respeito mais especificamente à História e ao seu ensino. Em fase posterior, este mesmo instrumento foi aplicado junto aos estudantes do Ensino Médio pelos graduandos.

Na sequência os grupos foram instados por outro instrumento, de matiz cognitiva, que permitiu a investigação a respeito dos conceitos meta-históricos (de segunda ordem) relacionados à história 6, isto é, a respeito da noção de verdade, temporalidade, evidência, etc.

Perguntas relacionadas à significância do que é "ser jovem", além de questões que trataram das perspectivas profissionais dos graduandos, como compreendiam a relação entre teoria e prática no curso de História, entre outras, também compuseram o segundo instrumento. No que concerne às especificidades do instrumento cognitivo voltado para os estudantes do Ensino Médio, questões referentes à concepção de História que possuem, ou mesmo a perspectiva que se tem sobre o ensino de história no tocante às metodologias, ao relacionamento com o professor, a livro didático, entre outros, integram a investigação. No presente artigo serão apresentamos resultados parciais que se relacionam com o "confronto" entre noções dos graduandos e dos estudantes de Ensino Médio.

\section{b) Da categorização analítica: as Representações Sociais}

Émile Durkheim, ainda no início do século XX, compreendeu que as representações são formas de integração social, elaboradas pelos seres humanos, cujo objetivo é construir

6 Os conceitos de segunda ordem são constitutivos da cognição histórica, dizem respeito aos fundamentos teó ricos e metodológicos da história, isto é, à natureza do conhecimento histórico, entre outros, explicação histórica, fontes e evidências históricas, consciência histórica, inferência e imaginação histórica, noções de tempo histórico, interpretação histórica, narrativa histórica (LEE, 2001). 
identidade com vistas à manutenção da coesão de um coletivo, de um grupo, bem como apresentar suas propostas para a vida cotidiana. Representações que, obviamente, se expressam por meio de instituições, discursos, imagens, normatizações, rituais, dentre outros, que criam uma realidade paralela à existência dos indivíduos, mas que os fazem vivenciá-las cotidianamente (PESAVENTO, 2003, p.39) Embora a contribuição de Durkheim tenha sido fulcral no tocante ao estudo das representações, seu comprometimento histórico com a Sociologia, de certa forma, limitou o alcance de sua conceituação, tal como afirma DUVENN (2003, p.15)

O esforço para estabelecer a sociologia como uma ciência autônoma levou Durkheim a defender uma separação radical entre representações individuais e coletivas e a sugerir que as primeiras deveriam ser no campo da psicologia, enquanto as últimas formariam o objeto da sociologia $[. .]$.$" .$

Moscovici, por sua vez, compreende que para entender as representações não basta limitar-se à constatação conceitual de sua ocorrência, mas se faz necessário desvelar aspectos de sua natureza. Partindo da psicologia social, esse autor romeno, promove nova leitura, pois as considera como fenômenos que ocorrem com os indivíduos e grupos sociais em suas relações cotidianas. Entender as representações como fenômeno é considerar sua condição de objeto a ser estudado por meio de uma dupla dimensão: em sua complexa estrutura e no alcance de sua influência. Nessa perspectiva, investigar representações é desvelar seu conteúdo, bem como compreendê-las como processo permanentemente dinâmico. Moscovici (2001, p.59) não apresenta essa nova concepção de representação de maneira fortuita, antes se fiou nos estudos de Piaget e Freud que, em suas pesquisas, investigaram os mecanismos de embate das crianças com os desafios de sua vivência diária. Ao discorrer sobre esse aspecto, Moscovici (2001, p.49) assevera que

[...] se, no sentido clássico [durkheiminiano], as representações coletivas se constituem em um instrumento explanatório e se referem a uma classe geral de idéias e crenças (ciência, mito, religião, etc), para nós, são fenômenos que necessitam ser descritos e explicados. São fenômenos específicos que estão relacionados com um modo particular de compreender e de se comunicar - um modo que cria tanto a realidade como o senso comum. É para enfatizar essa distinção que eu uso o termo 'social' em vez de 'coletivo. 
A compreensão de Moscovici de que as representações são fenômenos socialmente relacionados à construção do conhecimento no campo do senso comum, abre espaço para criticar-se a postura adotada por algumas correntes das ciências humanas que afirmam que grupos e indivíduos são controlados por ideologias impostas pelo Estado, igreja, escola ou outro tipo de instituição. Ora, se tal raciocínio for pertinente, a qualquer coletividade caberia apenas reproduzir o desejo de instituições prescritoras de mandamentos de orientação temporal, sendo, portanto, apenas depositária de ideologias. Tal compreensão reproduz a versão limitada de que há um imperativo de representações que se restringe apenas a uma elite da sociedade que monopoliza sua criação e instauração. As representações teriam apenas a função instrumental de reprodução coletiva limitada a promover a vontade ideológica da minoria detentora do poder. Esse é o grande diferencial existente entre o conceito clássico de representação coletiva de Durkheim e a alternativa proposta por Moscovici: a representação social. Assim,

[...] estudar representações sociais implica adentrar a densidade de um espaço que (re)apresenta os seres humanos em seus pensamentos, em suas formas de estar e de compreender o mundo, em seus questionamentos, em suas opções históricas, independentemente de suas características socioeconômicas, culturais ou políticas. Portanto, as representações tornam-se sociais quando consideram diferentes aspectos da sociedade, principalmente o conhecimento gerado que comumente é denominado de senso comum. (ALVES, 2014b, p.279).

O sistema de representações de dado grupo social permite a troca simbólica, a interação, a comunicação e é formado por um perfil cultural composto de códigos linguísticos e ideológicos. Pessoas de um mesmo grupo podem falar uma mesma linguagem cultural, mas não compartilharem, necessariamente, as mesmas ideias. Os sujeitos vivem em determinadas formações socioculturais que não determinam, mas podem ser eixos explicativos quanto às suas representações. Nesse sentido, a presente pesquisa partiu de parâmetros que compõem os perfis dos grupos pesquisados, tais como religião, classe socioeconômica, sexo, nível de instrução, etnia, nacionalidade, entre outras. A coleta desses dados obedeceu um processo de investigação que partiu, como observado anteriormente, da compreensão dos grupos a respeito do termo "juventude", bem como de seu entendimento a respeito da História e seu Ensino. 


\section{Nosso "jovem" pesquisador}

Qual perfil dos jovens participantes da pesquisa? Os graduandos do $4^{\circ}$ ano do curso de História da UEL partilhavam da faixa etária entre 21 e 25 anos. Embora em contato com estes estudantes do Ensino Médio no campo de pesquisa, o compreendiam como "adolescentes" e a si mesmos como "jovens ou adultos", não atinavam para a pouca diferença de idade entre tais grupos, pois a idade máxima dos "adolescentes" do Ensino Médio era de 18 anos, enquanto a idade mínima dos “jovens/adultos” era de 21 anos. Os estudantes de Ensino Médio, por sua vez, também se compreendem como jovens, não como adolescentes, mesmo com a idade média variando entre 14 e 18 anos.

A quantidade de pessoas participantes de cada grupo também variou. Na tabela 1 verifica se que o grupo de 89 graduandos participantes da pesquisa, tinha maior percentagem de mulheres (58,4\%), sobretudo nos anos letivos de 2013 (57,7\%) e 2014 (73,9\%).

Tabela 1 - Quantidade de graduandos participantes da pesquisa

\begin{tabular}{|c|c|c|c|}
\hline ANO & GRADUANDOS & SEXO & $\%$ \\
\hline \multirow{2}{*}{2011} & & & $50 \%$ \\
\hline \multirow{2}{*}{2012} & 26 & 13 homens & $50 \%$ \\
\cline { 3 - 4 } & & 13 mulheres & $50 \%$ \\
\hline \multirow{2}{*}{2013} & \multirow{2}{*}{26} & 7 homens & $50 \%$ \\
\cline { 3 - 4 } & & 7 mulheres & $42,3 \%$ \\
\hline \multirow{2}{*}{2014} & \multirow{2}{*}{23} & 11 homens & $57,7 \%$ \\
\hline \multirow{2}{*}{ TOTAL } & \multirow{2}{*}{89} & 15 mulheres & $26,1 \%$ \\
\cline { 3 - 4 } & & 17 mulheres & $73,9 \%$ \\
\cline { 3 - 4 } & & 37 homens & $41,6 \%$ \\
\hline
\end{tabular}

Fonte: Os autores.

As questões realizadas aos graduandos e aos estudantes de Ensino Médio foram elaboradas conforme a demanda da pesquisa em curso. As respostas demonstram similaridades e distinções entre estes dois grupos, no que concerne à construção de sua identidade/alteridade. As respostas apontam para uma noção fundamental: os graduandos já se entendem com adultos, enquanto que os estudantes do Ensino Médio se entendem como jovens. 
O que pôde se observar nestes grupos de alunos do curso de licenciatura, é que todos ficaram inseguros em realizar a pesquisa, com o argumento de que o curso de História não prepara para tal. É um grupo composto pela maioria branca, de classe socioeconômica média, com poucos cotistas e, majoritariamente, de religião católica. A internet era utilizada por todos, por meio de aparelhos celulares que todos do grupo possuíam. Somente nove pessoas (oito homens e uma mulher) do total de 89 pessoas, tinham carro, além de dois homens que possuíam motocicleta. Estes jovens, costumam utilizar as mesmas marcas simbólicas: roupas, acessórios, celulares, etc.

No que concerne à preferência musical, os graduandos demonstraram gostar de todos os gêneros de rock e de música popular brasileira. Gêneros literários variados são objeto de leitura, tanto de autores nacionais como internacionais. Assistir televisão, passear no shopping e acessar internet são preferências de lazer, com alusão à ida ao teatro feita apenas por cinco mulheres, e a participação em grupo de jovens da igreja, mencionada por uma outra mulher. É comum a frequência às festas universitárias. Com seu dinheiro, adquirido por mesada ou trabalho, costumam comprar livros e roupas, bem como tirar fotocópias para o curso. Predominantemente conversam a respeito de seus problemas e perspectivas com os amigos, pois confiam muito mais neles do que em familiares, professores ou líderes religiosos.

Em relação à política, percebe-se que a crítica a respeito da administração pública no Brasil teve notório adensamento ao longo dos quatro anos de pesquisa. Nos dois últimos anos (2013/2014) houve uma variável significativa: principalmente os homens passaram a enxergar a administração pública do Brasil de forma negativa. Observa-se que, em 2014, quatro homens e uma mulher se manifestaram, por meio do questionário, como sendo contra cotas, apontando que negros, indígenas e mulheres eram vitimizados pelo governo7. Um dos pesquisados comentou que o curso de História procura formar professores "de esquerda" que ensinam uma História que enfatiza a desigualdade social, e completa: "se houvesse o estudo da história real, veríamos que o indígena está no neolítico e não pode ser respeitado na sua cultura atrasada".

Mas o que pensa esse grupo de futuros professores pesquisados que, em sua maioria, é constituído por pessoas brancas, de classe média e de religiosidade católica, a respeito de sua própria futura profissão: a docência? Como veem sua formação universitária? O que pensam a respeito de sua ciência de referência na formação: a História? Qual o olhar que eles têm a respeito de seus futuros alunos, com os quais se deparam nas atividades de formação docente na escola básica?

7 À época da coleta de dados do último grupo pesquisado(2014), o país era governado por Dilma Roussef, no último ano de sua primeira gestão (2011-2014). 


\section{a) Representações dos futuros professores a respeito da profissão docente}

Antes de categorizar as representações que os futuros professores têm a respeito da docência que exercerão após a formação universitária, convém mencionar sua percepção sobre o término da juventude, pois tal definição está diretamente relacionada às questões do trabalho, conforme pode ser observado na Tabela 2:

Questão - Quando a pessoa deixa de ser jovem?

Tabela 2- Opinião a respeito do tempo em que se deixa de ser jovem

\begin{tabular}{|c|c|c|c|c|}
\hline RESPOSTAS & SEXO & $\%$ & GRADUANDOS & $\%$ \\
\hline \multirow[t]{2}{*}{ Quando começa a trabalhar } & 27 homens & $73(27 / 37)$ & \multirow[t]{2}{*}{54} & \multirow[t]{2}{*}{60,7} \\
\hline & 27 mulheres & $52(27 / 52)$ & & \\
\hline \multirow[t]{2}{*}{ Independência financeira } & 2 homens & $5,4(2 / 37)$ & \multirow[t]{2}{*}{10} & \multirow[t]{2}{*}{11,2} \\
\hline & 8 mulheres & $15,4(8 / 52)$ & & \\
\hline \multirow{2}{*}{$\begin{array}{l}\text { Quando termina um curso } \\
\text { superior }\end{array}$} & 5 homens & $13,5(5 / 37)$ & \multirow[t]{2}{*}{10} & \multirow[t]{2}{*}{11,2} \\
\hline & 5 mulheres & $9,6(5 / 52)$ & & \\
\hline \multirow[t]{2}{*}{ Família/Filhos } & 2 homens & $5,4(2 / 37)$ & \multirow[t]{2}{*}{14} & \multirow[t]{2}{*}{15,7} \\
\hline & 12 mulheres & $23(12 / 52)$ & & \\
\hline Idade & 1 homem & $2,7(1 / 37)$ & 1 & 1,2 \\
\hline TOTAL & \multicolumn{4}{|c|}{89} \\
\hline
\end{tabular}

Fonte: Os autores.

Para $60,7 \%$ dos graduandos pesquisados é a relação com o trabalho que põe fim à juventude e inaugura a fase adulta. A organização de uma família (15,7\%), o término da faculdade $(11,2 \%)$ ou a independência financeira $(11,2 \%)$ não seriam motivos estruturais que tornam a pessoa adulta. Entretanto, quando se observa os mesmos dados no tocante à visão, especificamente, de homens e mulheres, há um aumento desta compreensão nos homens (73\%) e uma redução pequena no entendimento das mulheres (52\%). Diminuição que é substituída pela ideia de que a constituição de família e filhos é quem determina o fim da juventude (23\%) ou a independência financeira $(15,4 \%)$, fatores que têm incidência bem menor entre os homens $(5,4 \%$ nos dois itens).

Ora, se se pensar que no Brasil há parte considerável de adolescentes e jovens que deixam a escola, sobretudo no Ensino Médio, para trabalharem, além do aviltante trabalho infantil que ainda perdura, concomitantemente, nos rincões do país, seja em minas ou fazendas, por exemplo, ou mesmo nas grandes cidades, em meio aos malabares em semáforos do trânsito ou na comercialização do mercado informal em diferentes zonas de comércio popular, nos diferentes transportes coletivos como trens, ônibus e metrô, pode-se concluir que para muitos 
a fase adulta, infelizmente, consome a infância e a juventude. Possivelmente os graduandos, ao se colocarem dessa forma, estavam pensando que sua própria emancipação profissional se identificaria com a ascensão à fase adulta, entretanto, o cotejamento desses dados com a dura realidade observada nas ruas e sertões do Brasil, abre espaço para pensar que tal relação com o trabalho pressupõe opressão. Verifica-se, também, que o fato de as mulheres relacionarem o fim da juventude com a constituição de família e independência financeira, em percentagem bem maior que os homens, denota que elas enxergam a questão do trabalho de forma menos individualista que os homens, seja porque veem no trabalho a perspectiva de independência financeira e, consequentemente sua autonomia, seja porque a responsabilidade familiar cai somente em seus ombros, dado que muitas crianças, sobretudo nos estratos mais pobres da sociedade, são criadas somente pela mãe.

Essa percepção do grupo se coaduna, na altura em que a pesquisa foi feita em cada ano, com parte importante de graduandos que já trabalhava, conforme pode ser constatado na Tabela 3:

Questão - Você trabalha?

Tabela 3- Incidência de estudantes que trabalham

\begin{tabular}{|c|c|c|c|c|}
\hline RESPOSTAS & GRADUANDOS & $\%$ & SEXO & $\%$ \\
\hline Não & 60 & & 20 homens & $54(20 / 37)$ \\
\cline { 4 - 5 } & & & 40 mulheres & $76,9(40 / 52)$ \\
\hline \multirow{2}{*}{ Sim } & 29 & 32,6 & 17 homens ${ }^{8}$ & $45,9(17 / 37)$ \\
\cline { 4 - 5 } & & & 12 mulheres & $23,1(12 / 52)$ \\
\hline TOTAL & \multicolumn{3}{|c}{$\mathbf{8 9}$} \\
\hline
\end{tabular}

Fonte: Os autores.

Praticamente um terço dos graduandos trabalhavam no período em que participaram da pesquisa, sendo $45,9 \%$ dos homens e $23,1 \%$ das mulheres pesquisadas. Fator que pode ter relação direta com o que se observa na Tabela 4, pois quando se pensa na expectativa de homens e mulheres no tocante ao desejo de ser professor ao adentrar um curso de licenciatura, verifica-se que a maioria daqueles que expectaram ser docente se relaciona, maciçamente, às mulheres. O quadro mostra que $75,3 \%$ dos graduandos almejavam ser professor quando adentraram ao curso, porém este grupo é formado, majoritariamente, por mulheres (92,37\% delas). Porcentagem que se inverte quando verificamos os dados daqueles que não desejavam ser professor quando da entrada no curso de História (15,7\% do total de 89

8 Do período matutino, apenas 8 trabalhavam. 
graduandos - 14 pessoas, sendo 92,9\% deste grupo formado por homens (35,1\% deles). Esse dado, relacionado aos demais, mostra a procura pelas mulheres pela profissão docente.

Questão - Você entrou no curso querendo ser professor?

Tabela 4 Incidência de perspectiva, no início do curso, de ser professor

\begin{tabular}{|c|c|c|c|c|}
\hline RESPOSTAS & GRADUANDOS & $\%$ & SEXO & $\%$ \\
\hline \multirow[t]{2}{*}{ Sim } & \multirow[t]{2}{*}{67} & \multirow[t]{2}{*}{75,3} & 19 homens & $51,4(19 / 37)$ \\
\hline & & & 48 mulheres & $92,3(48 / 52)$ \\
\hline \multirow[t]{2}{*}{ Não } & \multirow[t]{2}{*}{14} & \multirow[t]{2}{*}{15,7} & 13 homens & $35,1(13 / 37)$ \\
\hline & & & 1 mulheres & $1,9(1 / 52)$ \\
\hline \multirow[t]{2}{*}{ Mais ou menos } & \multirow[t]{2}{*}{8} & \multirow[t]{2}{*}{9} & 5 homens & $13,5(5 / 37)$ \\
\hline & & & 3 mulheres & $5,8(4 / 52)$ \\
\hline
\end{tabular}

Fonte: Os autores.

Essa diferenciação entre a expectativa de homens e mulheres com relação ao curso de História da Universidade Estadual de Londrina se coaduna com outro dado importante: a discussão em torno da identidade formadora do curso - está mais voltada para formar o professor ou o pesquisador? Discussão sempre presente na tradiçãobacharelesca dos cursos de licenciatura em História brasileiros. Em que medida as licenciaturas têm valorizado a formação do professor? Os cursos de licenciatura em História, por sua vez, estão voltados, estruturalmente em seus currículos e projetos políticos pedagógicos, bem como na mentalidade de seus docentes, à preocupação em formar qualitativamente professores de História para a escola básica? Ou, por outro lado, têm desprezado essa formação, voltando-se para a formação qualitativa do pesquisador em História, com vistas à especialização que conduz à carreira acadêmica no Ensino Superior. Em curtas palavras: prefere-se formar historiadores ou professores de História? A efetivação de uma dessas opções anula a outra?

Ao debruçar-se sobre os dados da Tabela 5, percebe-se que há profícua relação com a Tabela 4. Veja que a maioria daqueles que desejavam ser professores era formada por mulheres na tabela anterior e, agora, verifica-se que esse grupo percebe o desencantamento com a expectativa que tinham quando da entrada no curso se comparada à sua experiência de formação, pois $41,6 \%$ dos pesquisados compreendem que o curso da UEL se volta para formar, prioritariamente, o pesquisador, sendo que este montante é formado, em especial, por mulheres (50\%). O inverso é o que se percebe quando é analisada a porcentagem de graduandos pesquisados que disseram ser o curso voltado para formar professores de História (25,8\%). Grupo que é formado por $40,5 \%$ de homens. 
Esses dados mostram que a maioria das mulheres desejavam cursar História para serem professoras, porém na prática verificaram que suas expectativas foram desprezadas, pois a prioridade da universidade está em formar, em seu entendimento, pesquisadores. Parte considerável dos homens, por sua vez, adentraram o curso expectando formarem-se pesquisadores, porém entendem que a formação priorizada é a de professor. Interessante observar, também, que poucas mulheres trabalhavam concomitantemente aos estudos e, por isso, desejavam o exercício da profissão docente na escola de educação básica e, por consequência, a independência proporcionada pelo adentrar à "fase adulta" (cf. análise das tabelas 2 e 3).

Questão - $O$ curso prepara para ser professor ou pesquisador?

Tabela 5: Opinião a respeito do preparo que o curso oferece aos alunos para serem professores e/ou pesquisadores

\begin{tabular}{|c|c|c|c|c|}
\hline RESPOSTAS & SEXO & $\%$ & GRADUANDOS & $\%$ \\
\hline \multirow[t]{2}{*}{ Pesquisador } & 11 homens & $29,7(11 / 37)$ & \multirow[t]{2}{*}{37} & \multirow[t]{2}{*}{41,6} \\
\hline & 26 mulheres & $50(26 / 52)$ & & \\
\hline \multirow[t]{2}{*}{ Professor } & 15 homens & $40,5(15 / 37)$ & \multirow[t]{2}{*}{23} & \multirow[t]{2}{*}{25,8} \\
\hline & 8 mulheres & $15,4(8 / 52)$ & & \\
\hline \multirow{2}{*}{$\begin{array}{llll}\text { Nem uma } & \text { coisa nem } \\
\text { outra } & & & \\
\end{array}$} & 4 homens & $10,8(4 / 37)$ & \multirow[t]{2}{*}{11} & \multirow[t]{2}{*}{18} \\
\hline & 7 mulheres & $13,5(7 / 52)$ & & \\
\hline \multirow[t]{2}{*}{ Para os dois } & 7 homens & $18,9(7 / 37)$ & \multirow[t]{2}{*}{18} & \multirow[t]{2}{*}{20,2} \\
\hline & 11 mulheres & $21,2(11 / 52)$ & & \\
\hline TOTAL & \multicolumn{4}{|c|}{89} \\
\hline
\end{tabular}

Fonte: Os autores.

Os dados apresentados até aqui coadunam com a ideia de que somente o trabalho contemplará o sonho almejado da melhora de vida, pois promoverá a elevação à fase adulta para a maioria desses estudantes. Daí o fato de quase a metade do grupo pesquisado (48,3\%) ter a compreensão de que a vida melhorará somente se abrir-se uma oportunidade de emprego após a universidade. Algo ainda mais claro se pensar nas mulheres pesquisadas, pois a maioria das graduandas compreende ser a consecução de um emprego $(53,8 \%)$ ou o fato de se formar na Universidade (23,1\%), caminhos profícuos para a melhora de vida. 
Questão - Como você acha que a vida vai melhorar?

Tabela 6: Sobre noção quanto à melhoria de vida

\begin{tabular}{|l|c|c|c|c|}
\hline \multicolumn{1}{|c|}{ RESPOSTAS } & GRADUANDOS & $\%$ & SEXO & $\%$ \\
\hline Conseguirei emprego & 43 & 48,3 & 15 homens & $40,5(15 / 37)$ \\
\cline { 4 - 5 } & & & 28 mulheres & $53,8(28 / 52)$ \\
\hline Me formarei & 17 & 19,1 & 5 homens & $13,5(5 / 37)$ \\
\cline { 4 - 5 } & & 19,1 & 8 mulheres & $23,1(12 / 52)$ \\
\hline $\begin{array}{l}\text { Terei independência } \\
\text { familiar }\end{array}$ & 17 & 12,4 & 9 mulheres & $21,6(8 / 37)$ \\
\hline $\begin{array}{l}\text { Melhorará } \\
\text { administração pública do } \\
\text { Brasil }\end{array}$ & 11 & & 2 mulheres & $24,3(9 / 52)$ \\
\hline Piorará & & 1,1 & 1 mulher & $1,9(2 / 57)$ \\
\hline TOTAL & 1 & \multicolumn{3}{|l|}{89} \\
\hline
\end{tabular}

Fonte: Os autores.

Conclui-se nesta primeira análise que somente o trabalho poderá contribuir para a melhora de vida, principalmente a das mulheres, pois elas demonstram o anseio de adentrar a universidade em busca da empregabilidade como professoras. Quando, na prática, observam que a formação docente universitária está longe de ter melhoria de qualidade, dada a mentalidade bacharelesca que grassa nos cursos de licenciatura em História do Brasil, há um desencantamento devido à não satisfação do horizonte de expectativa vivenciada na experiência de curso. Os homens, por sua vez, por terem maior vivência no mundo do trabalho dentro deste grupo pesquisado, nem sempre adentraram o curso de História com o desejo de ser professor, mas a ânsia de satisfazer seus anseios de pesquisa em um curso em que compreendem ser voltado à docência. Representações diversificadas surgiram no processo de discussão da formação de professores, pois homens e mulheres nutriram expectativas diferentes em relação ao curso e, principalmente, compreenderam a formação distintamente. Claro está que as carências de orientação temporal desses grupos são muito diferenciadas e, portanto, apontam para distintas identidades.

Se o desencantamento ocorre com a maior parte do grupo de graduandos pesquisados internamente à formação universitária dos professores de História, o que pode ser constatado do ponto de vista externo, ou seja, relacionado à formação docente na prática da escola de educação básica?

b) Representações dos futuros professores a respeito do Ensino Médio

A representação feita pelos estudantes da graduação, de que o final da juventude está diretamente relacionado à entrada no mercado de trabalho e, consequentemente, à 
construção de sua própria autonomia econômica, se concretiza nas representações criadas a respeito dos jovens estudantes do Ensino Médio, bem como de sua própria atuação como professores. É o que se depreende da análise realizada a partir de questões do questionário que remetiam ao ato de lecionar no Ensino Médio, como observado na sequência.

Questão: Como você se sente ao pensar em ministrar aulas no Ensino Médio como estagiário ou já formado?

Tabela 7: O que pensa sobre lecionar no Ensino Médio

\begin{tabular}{|c|c|c|c|c|}
\hline RESPOSTAS & SEXO & $\%$ & GRADUANDOS & $\%$ \\
\hline \multirow{2}{*}{$\begin{array}{l}\text { Receoso (a), pois adolescentes são } \\
\text { indisciplinados ou rebeldes }\end{array}$} & 11 homens & 29,7 & \multirow[t]{2}{*}{29} & \multirow[t]{2}{*}{32,6} \\
\hline & 18 mulheres & 34,6 & & \\
\hline \multirow{2}{*}{$\begin{array}{l}\text { Receoso (a), pois adolescentes são } \\
\text { desrespeitosos com o (a) professor (a) }\end{array}$} & 8 homens & 21,6 & \multirow[t]{2}{*}{26} & \multirow[t]{2}{*}{29,2} \\
\hline & 18 mulheres & 34,6 & & \\
\hline \multirow{2}{*}{$\begin{array}{l}\text { Com a expectativa que me darei bem } \\
\text { com eles, pois adolescentes são mais } \\
\text { dinâmicos e aprendem rápido }\end{array}$} & 10 homens & 27 & \multirow[t]{2}{*}{18} & \multirow[t]{2}{*}{20,2} \\
\hline & 8 mulheres & 15,4 & & \\
\hline \multirow[t]{2}{*}{ Não sabe ou não respondeu } & 8 homens & 21,6 & \multirow[t]{2}{*}{16} & \multirow[t]{2}{*}{18} \\
\hline & 8 mulheres & 15,4 & & \\
\hline
\end{tabular}

Fonte: Os autores.

É impressionante verificar o temor que os graduandos têm da sala de aula. Uma espécie de "síndrome do pânico" de um espaço que ainda não habitaram como professores. Pelo contrário, ainda há pouco tempo estavam neste espaço como estudantes. É o que se pode depreender da análise da Tabela 7 , pois $61,8 \%$ dos graduandos representam os adolescentes como "indisciplinados e rebeldes" (32,6\%) ou "desrespeitosos para com o professor" $(29,2 \%)$. Percentual ainda maior quando se analisa somente as futuras docentes $(69,2 \%)$, se comparado aos futuros professores (51,3\%). Dados que se invertem quando se representa o estudante do Ensino Médio como "dinâmico, e que aprende rápido", pois dos $20.2 \%$ dos docentes que compreendem que farão excelente trabalho com esse perfil de estudantes, $27 \%$ são homens e, somente $15,4 \%$ são mulheres.

A dificuldade dos graduandos quanto ao Ensino Médio com seus alunos não está pautada somente no quesito disciplinar, mas também no cognitivo, pois $73 \%$ dos graduandos pesquisados representam tais estudantes como não afeitos a leitura (Tabela 8), mas diferentemente do item anterior, são predominantemente os docentes homens que pensam assim (81\%), ao passo que $67,3 \%$ das mulheres pesquisadas concordam com essa vi são. 
Questão: Você acha que os estudantes de Ensino Médio leem?

Tabela 8: Sobre a leitura dos alunos no Ensino Médio

\begin{tabular}{|c|c|c|c|c|}
\hline RESPOSTAS & SEXO & $\%$ & GRADUANDOS & $\%$ \\
\hline \multirow[t]{2}{*}{ Não } & 30 homens & $81(30 / 37)$ & \multirow[t]{2}{*}{65} & \multirow[t]{2}{*}{73} \\
\hline & 35 mulheres & $67,3(35 / 52)$ & & \\
\hline \multirow[t]{2}{*}{ Sim } & 4 homens & $10,8(4 / 37)$ & \multirow[t]{2}{*}{13} & \multirow[t]{2}{*}{14,6} \\
\hline & 9 mulheres & $17,3(9 / 52)$ & & \\
\hline \multirow[t]{2}{*}{ Não sabe } & 3 homens & $8,1(3 / 37)$ & \multirow[t]{2}{*}{11} & \multirow[t]{2}{*}{12,4} \\
\hline & 8 mulheres & $15,4(8 / 52)$ & & \\
\hline TOTAL & \multicolumn{4}{|c|}{89} \\
\hline
\end{tabular}

Fonte: Os autores.

A representação crítica torna-se exponencial quando em voga se coloca a temática da política. A totalidade dos futuros professores que opinaram compreendem ser os estudantes do Ensino Médio alheios à política (94,6\%). Percentual que tem grande escala com as futuras professoras também (76,9\%), entretanto, para o segundo grupo ainda se vislumbra que há alguns discentes que se interessam pelo tema supracitado (9,6\%). Ao mirar a totalidade dos dados percebe-se que $84,3 \%$ dos graduandos representam os estudantes do Ensino Médio como desinteressados em política.

Questão: Você acha que os estudantes de Ensino Médio são interessados na política?

Tabela 9: Sobre interesse político dos estudantes do Ensino Médio

\begin{tabular}{|l|c|c|c|c|}
\hline \multicolumn{1}{|c|}{ RESPOSTAS } & SEXO & $\%$ & GRADUANDOS & $\%$ \\
\hline Não & 35 homens & $94,6(35 / 37)$ & 75 & 84,3 \\
\cline { 2 - 3 } & 40 mulheres & $76,9(40 / 52)$ & & \\
\hline Sim & 5 mulheres & $9,6(5 / 52)$ & 5 & 5,6 \\
\hline Não sabe & 2 homens & $5,4(2 / 37)$ & 9 & 10,1 \\
\cline { 2 - 3 } & 7 mulheres & $13,5(7 / 52)$ & & \\
\hline TOTAL & \multicolumn{4}{|c|}{89} \\
\hline
\end{tabular}

Fonte: Os autores.

Após a análise dos dados interpretados até aqui, depreende-se que os futuros docentes representam os estudantes do Ensino Médio como alunos indisciplinados e desrespeitosos, não leitores e, principalmente, desinteressados em política. Além disso, representam a si mesmos como professores temerosos da sala de aula, por sentirem-se despreparados para lidar com o público descrito. "Síndrome do pânico" que se desenvolveu não somente pelo fato de participarem de estágios e programas de formação docente num espaço escolar 
sistematicamente desarticulado pelos entes administrativos, mas também pelo desencantamento gerado na caminhada da formação universitária, pois ao defrontarem-se com um curso de licenciatura que estruturalmente não se preocupa em formar o professor, pois privilegia a constituição de pesquisadores especialistas cujo número ínfimo adentrará a academia, os graduandos futuros docentes veem-se, ao final de seus cursos, absolutamente desestimulados por julgarem-se incapazes e despreparados para lidar com tantas dificuldades na carreira dantes sonhada.

Até aqui dados relacionados aos graduandos participantes da investigação, bem como representações por eles criadas acerca dos estudantes de Ensino Médio e de si mesmos, pautaram o presente artigo, mas uma questão se apresenta. Quem são os estudantes cujas representações foram aqui expostas? Como se percebem no contexto intra e extraescolar? Se compreendem como adolescentes, jovens ou adultos? Em que medida se relacionam com o passado a partir do presente? Se identificam com o estudo da História?

\section{Quem são estes chamados "adolescentes" estudantes secundaristas?}

Todos os estudantes pesquisados são do Ensino Médio de uma escola pública localizada no centro da cidade de Londrina, Estado Paraná. Participaram 424 estudantes da pesquisa, sendo 226 homens (53,3\%) e 198 mulheres $(46,7 \%)$.

A escola é caracterizada por ser frequentada por alunos de médio poder aquisitivo ${ }^{9}$, embora se perceba que os graduandos tinham melhor condição social. Poucos se declaram negros (apenas 23 homens e 12 mulheres), porém se percebe que de fato existem poucos negros. Destes alunos, dois homens e uma mulher possuem carro, enquanto 9 homens possuem motocicleta. Existe um grande número de evangélicos (68 homens e 79 mulheres), como de católicos (102 homens e 99 mulheres), não havendo nenhum que se declarasse ateu.

9 Apesar de ser central, é frequentada por alunos e alunas moradores de bairros periféricos, o que demanda utilizar transporte público. A escola é por estes frequentada por estar próxima aos seus empregos, e não às suas moradias. 
Tabela 10 - Incidência de estudantes - Masculino/Feminino

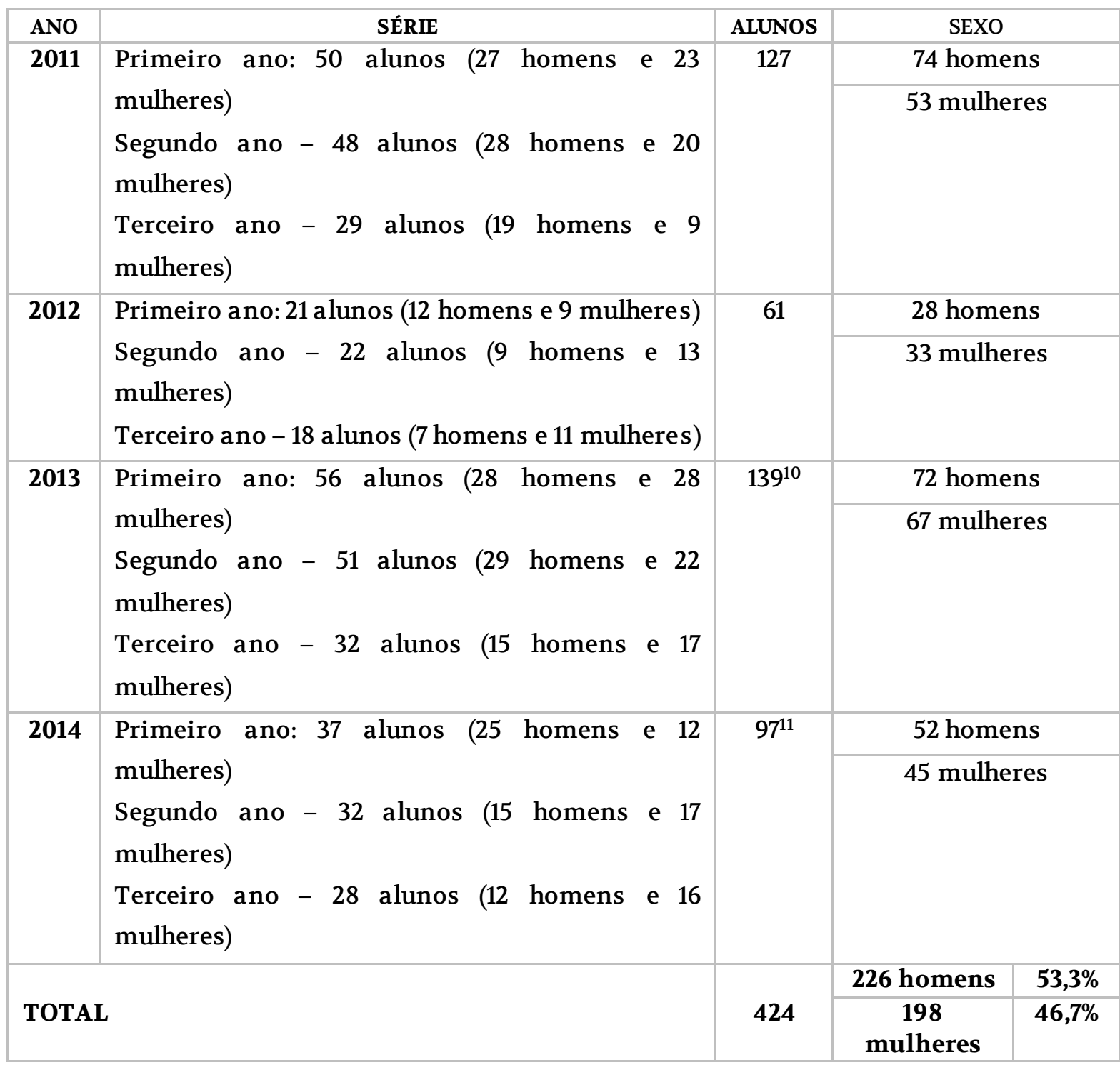

Fonte: Os autores.

São espíritas (12 homens e 10 mulheres), sendo que um homem se declarou umbandista. No entanto, muitos deixaram a resposta em branco. Estes jovens gostam de variados gêneros musicais, mas prevalece o rock como preferência maior. Diferentemente dos graduandos, os secundaristas não optaram pela música popular brasileira, mas o índice de predileção pelo sertanejo universitário é significativo (71 homens e 90 mulheres). Costumam comprar com seu salário ou mesada, principalmente roupas e aparelhos eletrônicos, mas um grande 
número diz que ajuda em casa com seu salário (enquanto que os universitários não chegaram a mencionar este fator). Os livros que dizem ler, geralmente são emprestados de amigos, parentes ou de bibliotecas (municipal ou da escola). Frequentam shoppings, igrejas e casa de amigos. Interessante é perceber que os grupos de jovens relacionados à igreja são uma constante na vida destes estudantes. Geralmente, o elo com a religião se dá através de amigos, muito mais do que com os pais. A pessoa com quem mais conversam sobre problemas e expectativas, ou seja, aquelas em quem mais confiam são, na sequência: 1) mãe; 2) pai; 3) amigos; 4) professores e 5) líderes religiosos ${ }^{12}$.

Todos tinham acesso à Internet, seja em casa, ou em lan houses. Lembraram que obter um computador tornara-se algo comum devido à facilidade de parcelamento de compra oferecido pelas lojas e que a hora/Internet nas lan houses era de custo muito baixo em seus respectivos bairros. Por serem alunos do período noturno, dizem não ter disponibilidade de tempo para assistir TV, mas que nos finais de semana, ou "de madrugada", compensavam o "tempo perdido na escola", acessando a Internet. Esta, considerada muito mais interessante, pois poderiam "baixar músicas e filmes", "bater papo no MSN"13, "assistir vídeos", "ouvir músicas", "jogar", "ver sites sobre fofoca", "fazer pesquisa escolar" (inclusive, sobre história). Ainda: poderiam utilizar sites relacionados às redes sociais elaborando álbuns de fotos, além de conversarem por tais sites e participarem de comunidades virtuais. Todas essas atividades, disseram fazer "ao mesmo tempo". Também se verificou que todos tinham aparelhos celulares.

\section{Mas como esses estudantes representam a juventude?}

Os estudantes secundaristas entrevistados, em sua maioria (47,2\%), compreendem que a juventude termina quando a pessoa "sai da casa dos pais", entretanto esse percentual é bem maior no caso dos entrevistados homens $(60,2 \%)$ se comparado às entrevistadas (32,3\%). A proporção é similar quando se pensa que a juventude termina quando "se começa a trabalhar", homens $26,1 \%$ e mulheres $16,1 \%$, em um total de $21,5 \%$ dos entrevistados. Importante mencionar que neste item, especificamente, há correspondência entre o que pensam os jovens graduandos e os adolescentes secundaristas entrevistados, inclusive com a maior incidência entre os homens.

12 As referências foram cruzadas. Um aluno poderia citar mais de uma pessoa.

13 MSN é um portal de conteúdo da Microsoft com notícias, fotos e vídeos, onde é possível estabelecer conversas on line em tempo real. 
Outra similaridade entre esses dois grupos se apresenta no tocante à maior incidência de mulheres que representam o fim da juventude como o fato de constituir "família/filhos" $(22,7 \%)$ e ter "independência financeira" $(14,1 \%)$, bem maior do que representado pelos homens (5,3\% e 4,4\%, respectivamente). Tal fator mostra que as mulheres, desde a sua juventude relacionam a constituição familiar com a independência financeira. Entretanto, tal relação nem sempre é acompanhada pela estruturação proveniente dos estudos e do trabalho, fator que demonstra a dificuldade das mulheres na sociedade brasileira, pois muitas vezes se tornam responsáveis por famílias sem o partilhar dessa responsabilidade com os homens.

Questão - Quando a pessoa deixa de ser jovem?

Tabela 11 - Opinião a respeito do tempo em que se deixa de ser jovem

\begin{tabular}{|c|c|c|c|c|}
\hline RESPOSTAS & SEXO & $\%$ & ALUNOS & $\%$ \\
\hline \multirow[t]{2}{*}{ Quando sai da casa dos pais } & 136 homens & $60,2(136 / 226)$ & \multirow{2}{*}{200} & \multirow[t]{2}{*}{47,2} \\
\hline & 64 mulheres & $32,3(64 / 198)$ & & \\
\hline \multirow[t]{2}{*}{ Quando começa a trabalhar } & 59 homens & $26,1(59 / 226)$ & \multirow[t]{2}{*}{91} & \multirow[t]{2}{*}{21,5} \\
\hline & 32 mulheres & $16,1(32 / 198)$ & & \\
\hline \multirow[t]{2}{*}{ Família/Filhos } & 12 homens & $5,3(12 / 226)$ & \multirow[t]{2}{*}{57} & \multirow[t]{2}{*}{13,4} \\
\hline & 45 mulheres & $22,7(45 / 198)$ & & \\
\hline \multirow[t]{2}{*}{ Não sabe ou não respondeu } & 10 homens & $4,4(10 / 226)$ & \multirow[t]{2}{*}{39} & \multirow[t]{2}{*}{9,2} \\
\hline & 29 mulheres & $14,6(29 / 198)$ & & \\
\hline \multirow[t]{2}{*}{ Independência financeira } & 9 homens & $4(9 / 226)$ & \multirow[t]{2}{*}{37} & \multirow[t]{2}{*}{8,7} \\
\hline & 28 mulheres & $14,1(28 / 198)$ & & \\
\hline TOTAL & \multicolumn{4}{|c|}{424} \\
\hline
\end{tabular}

Fonte: Os autores.

O trabalho e os estudos compõem o horizonte de expectativa dos secundaristas entrevistados para a tão almejada melhoria de vida. "Conseguir emprego" é o objeti vo de 51,7\% dos entrevistados (53,5\% de homens e 49,5\% de mulheres), bem como "passar no vestibular" para $30,7 \%$ dos inquiridos (28,3\% dos homens e 33,3\% das mulheres).

Questão - Como a vida melhoraria?

Tabela12 - Sobre noção quanto à melhoria de vida

\begin{tabular}{|c|c|c|c|c|}
\hline RESPOSTAS & SEXO & $\%$ & ALUNOS & $\%$ \\
\hline \multirow[t]{2}{*}{ Conseguir emprego } & 121 homens & $53,5(121 / 226)$ & \multirow[t]{2}{*}{219} & \multirow[t]{2}{*}{51,7} \\
\hline & 98 mulheres & $49,5(98 / 198)$ & & \\
\hline \multirow[t]{2}{*}{ Passar no vestibular } & 64 homens & $28,3(64 / 226)$ & \multirow[t]{2}{*}{130} & \multirow[t]{2}{*}{30,7} \\
\hline & 66 mulheres & $33,3(66 / 198)$ & & \\
\hline \multirow[t]{2}{*}{ Independência familiar } & 23 homens & $10,2(23 / 226)$ & \multirow[t]{2}{*}{48} & \multirow[t]{2}{*}{11,3} \\
\hline & 25 mulheres & $12,6(25 / 198)$ & & \\
\hline \multirow{2}{*}{$\begin{array}{c}\text { Melhor administração pública } \\
\text { do Brasil }\end{array}$} & 14 homens & $6,2(14 / 226)$ & \multirow[t]{2}{*}{22} & \multirow[t]{2}{*}{5,2} \\
\hline & 8 mulheres & $4(8 / 198)$ & & \\
\hline Vai piorar & 5 homens & $2,2(5 / 226)$ & 5 & 1,1 \\
\hline TOTAL & \multicolumn{4}{|c|}{424} \\
\hline
\end{tabular}

Fonte: Os autores. 
Percebe-se que as representações dos graduandos acerca dos adolescentes secundaristas, que sintetizavam a ideia de um grupo firmado no presente e, de certa forma, alienado politicamente, não coadunam com o que os estudantes do Ensino Médio pensam do que pretendem como jovens, pois maciçamente representam a concepção de que a juventude pode atuar como protagonista para a construção de novas experiências com vistas à contemplação de um horizonte expectado. É o que pode ser observado quando $82,3 \%$ dos entrevistados acreditam que o jovem pode mudar o mundo (88,5 dos adolescentes homens entrevistados e $75,3 \%$ das adolescentes entrevistadas).

\section{Questão - Os jovens podem mudar o mundo?}

Tabela 13 - Sobre capacidade de mudança que o jovem pode ter

\begin{tabular}{|c|c|c|c|c|}
\hline RESPOSTAS & SEXO & $\%$ & ALUNOS & $\%$ \\
\hline Podem mudar muito & 200 homens & $88,5(200 / 226)$ & 349 & 82,3 \\
\cline { 2 - 3 } & 149 mulheres & $75,3(149 / 198)$ & & \\
\hline \multirow{2}{*}{ Podem mudar um pouco } & 10 homens & $4,4(10 / 226)$ & \multirow{2}{*}{39} & 9,2 \\
\cline { 2 - 3 } & 29 mulheres & $14,6(29 / 198)$ & & \\
\hline \multirow{2}{*}{$\begin{array}{c}\text { Não sabe ou não } \\
\text { respondeu }\end{array}$} & 8 homens & $3,5(8 / 226)$ & 23 & 5,4 \\
\cline { 2 - 3 } Não podem mudar & 15 mulheres & $7,6(15 / 198)$ & & 3,1 \\
\cline { 2 - 3 } & 8 homens & $3,5(8 / 226)$ & \multirow{2}{*}{$2,5(5 / 198)$} & \\
\hline TOTAL & \multicolumn{2}{|c|}{$\mathbf{4 2 4}$} & \\
\hline
\end{tabular}

Fonte: Os autores.

Mas de que forma essa mudança seria empreendida? As representações dos secundaristas entrevistados apontam para um mundo que pode ser mudado por meio de ações em diferentes vertentes. Se de um lado, as transformações construídas pelos jovens adotariam o respeito à diversidade (34,4\%), a mentalidade que contempla o direito a alteridade, de outro a busca pela transcendência, a relação com o divino, a religiosidade (34,2\%), possibilitariam a produção de uma nova sociedade. Verifica-se, portanto, a construção de uma consciência histórica que representa o protagonismo da juventude com sua ação histórica para a consecução do acolhimento da diferença, com outro tipo de consciência histórica, na qual o ser humano é representado como alvo, objeto da transcendência, cuja transformação decorre da ação divina no humano. Observa -se, aqui, o encontro de diferentes tipos de consciência histórica (moderna e pré-moderna) ${ }^{14}$, cuja finalidade é prover as pessoas de orientação temporal e construção identitária. 
Convém mencionar que ambos os itens, embora representantes de tipos de consciência histórica ${ }^{15}$ totalmente diferentes, apresentam uma identidade juvenil firmada em bases culturais. Ações de protagonismo da juventude, com características firmadas em bases socioeconômicas, tais como "igualdade de oportunidade", "dedicação ao trabalho" e "justiça social", ou mesmo em bases políticas - "respeito ao meio ambiente" - tiveram incidência bem menor se comparado ao protagonismo de base cultural acima apresentado.

Quais seriam os valores para uma sociedade ideal?

Tabela 14: Sobre os valores essenciais para a vida

\begin{tabular}{|c|c|c|c|c|}
\hline RESPOSTAS & SEXO & $\%$ & ALUNOS & $\%$ \\
\hline \multirow{2}{*}{ Respeito às diferenças } & 79 homens & $34,9(79 / 226)$ & \multirow{2}{*}{146} & \multirow[t]{2}{*}{34,4} \\
\hline & 67 mulheres & $33,8(67 / 198)$ & & \\
\hline \multirow{2}{*}{$\begin{array}{llll}\text { Temor a } & \text { Deus } & \text { ou } \\
\text { religiosidade } & & \\
\end{array}$} & 73 homens & $32,3(73 / 226)$ & \multirow[t]{2}{*}{145} & \multirow[t]{2}{*}{34,2} \\
\hline & 72 mulheres & $36,3(72 / 198)$ & & \\
\hline \multirow[t]{2}{*}{ Igualdade de oportunidade } & 32 homens & $14,2(32 / 226)$ & \multirow[t]{2}{*}{58} & \multirow[t]{2}{*}{13,7} \\
\hline & 26 mulheres & $13,1(26 / 198)$ & & \\
\hline \multirow[t]{2}{*}{ Dedicação ao trabalho } & 23 homens & $10,2(23 / 226)$ & \multirow[t]{2}{*}{35} & \multirow[t]{2}{*}{8,3} \\
\hline & 12 mulheres & $6,1(12 / 198)$ & & \\
\hline \multirow[t]{2}{*}{ Justiça social } & 15 homens & $6,6(15 / 226)$ & \multirow[t]{2}{*}{24} & \multirow[t]{2}{*}{5,7} \\
\hline & 9 mulheres & $4,5(9 / 198)$ & & \\
\hline \multirow[t]{2}{*}{ Respeito ao meio ambiente } & 4 homens & $1,8(4 / 226)$ & \multirow[t]{2}{*}{16} & \multirow[t]{2}{*}{3,7} \\
\hline & 12 mulheres & $6,1(12 / 198)$ & & \\
\hline TOTAL & \multicolumn{4}{|c|}{424} \\
\hline
\end{tabular}

Fonte: Os autores.

Se as representações de juventude entre jovens graduandos e jovens secundaristas se encontram em quesitos como a relação com o trabalho, por exemplo, demonstraram-se distintas no tocante ao que os futuros professores entendiam ser a relação dos estudantes do Ensino Médio com o tempo. Nesse sentido, convém perguntar qual a relação que estes grupos

15 Quatro são os tipos de consciência histórica para Rüsen (2010). O primeiro deles, denominada consciência histórica tradicional se relaciona à permanência inquestionável de valores morais e modos de vida tradicionalmente estabelecidos, dando assim, ao tempo, um caráter estável e repetitivo. A consciência histórica exemplar, por sua vez, mostra o passado como fornecedor de princípios que podem ser usados como modelo para situações de vida no presente, independentemente das mudanças ocorridas na sociedade ao longo do tempo. Trata- se do que o filósofo da Antiguidade Cícero chamou de Historia Magistra Vitae - "História Mestra da Vida"(KOSELLECK, 2006). Consciência histórica crítica é a denominação do terceiro tipo de constituição de sentido à História elaborado por Rüsen. A postura de embate em relação aos valores morais tradicionalmente estabelecidos é característica dessa concepção, pois pensa cultura como algo que se transforma historicamente e, por isso, modelos de orientação prescritos pela sociedade podem ser criticados e, até mesmo, rejeitados. Por fim, a consciência histórica genética se caracteriza por uma relação dialógica com o passado. Nela, mudanças e permanências são historicizadas, bem como a experiência histórica interpretada à luz de um pensamento histórico que considera diferentes perspectivas. Tais fatores, relacionados, demandam reflexão constante, permitindo a geração contínua de novas possibilidades à orientação temporal. (ALVES, 2013). 
tem com a História e seu ensino. Em que medida o estudo da História no âmbito escolar contempla as demandas de orientação temporal e de construção de identidade desses estudantes, ou seja, a formação do pensamento histórico com vistas à ação consciente na História?

\section{Representações sobre a Aprendizagem e o Ensino de História para os futuros professores}

Para que serve a História? Essa pergunta clássica, objeto de discussão entre historiadores, professores de História, graduandose, até mesmo, estudantes da escola básica, se faz presente em diferentes momentos da caminhada de estudos desta disciplina.

Os futuros professores, graduandos da licenciatura pesquisados, não apresentam uma visão com maior predominância a este respeito. Para $36 \%$ dos pesquisados, o ensino de História tem a função de "desenvolver um pensamento crítico da realidade", ou seja, a aprendizagem histórica tem a função prática de contribuir para que as pessoas reflitam a respeito do seu cotidiano, orientem-se no presente, raciocinando sobre as opções que farão para dar conta dos desafios que lhes são colocados diariamente. Nessa mesma perspectiva, 20,2\% dos pesquisados entendem que a função do ensino de História é "relacionar passado, presente efuturo", ou seja, independentemente de maior ou menor pensamento crítico acerca da realidade, para esses graduandos aprender História é aprender a relacionar as diferentes temporalidades. Verifica-se, portanto, que as visões acerca da importância do ensino de História até aqui apresentadas se referem à consciência histórica demonstrada pelas pessoas para consigo, para com a sociedade e mundo, pois ambas são representadas pela orientação temporal e constituição de identidade.

"Construir o pensamento histórico", por sua vez, é a visão que $27 \%$ dos futuros professores têm a respeito da função do ensino de História. Diferentemente das duas respostas aqui abordadas, que tratam do aspecto prático da aprendizagem histórica, essa perspectiva trabalha algo anterior, apriorístico: a formação do pensamento histórico dos estudantes com vistas à promoção de uma análise crítica de sua realidade e do seu mundo. Nesse sentido, a aprendizagem histórica contribuiria para que as pessoas construíssem a compreensão de serem intérpretes de suas próprias experiências temporais, das ações da sociedade e do mundo, no processo histórico, com vistas à elaboração de perspectivas de novas ações, individuais e coletivas no tempo. 
Se as duas opções iniciais tratam da ação (consciência histórica) a partir da cognição histórica construída (pensamento histórico), a última volta-se para a construção da cognição (pensamento histórico) geradora da ação histórica (consciência histórica). Trata-se da relação entre o "aparente" e o "latente". Comumente entende-se que se o estudante conseguir refletir a respeito de sua sociedade ou com as diferentes temporalidades, ou seja, o que é "aparente", o objetivo do ensino de História terá sido alcançado. Entretanto, porque não se pensar num ensino de História que discuta também com seus estudantes o que normalmente é "latente"? Em outras palavras, porque não mostrar aos estudantes de História da escola básica como, em seus estudos históricos, ocorre o processo de desenvolvimento da cognição histórica, por meio da investigação de fontes, da relação com a temporalidade e da construção narrativa com vistas à assunção de ideias históricas potentes que permitam a acurada interpretação da realidade? A compreensão tanto do resultado quanto do processo de construção da racionalidade histórica potencializará as ideias históricas dos estudantes de forma a possibilitar a formação do pensamento histórico conectada, conscientemente, à realidade. em um tempo em que ocorre a ascensão de narrativas históricas conservadoras e, até, fundamentalistas, em que as temporalidades tornam-se unificadas num modelo solo de orientação temporal no campo da economia (não há alternativa factível para além do capitalismo) e político-sociocultural (não há alternativas, em alguns países, aos modelos religiosos fundamentalistas que vinculam religião e estado), discutir a relação entre a formação do pensamento histórico (o latente) com a vivência consciente da História (o aparente) torna-se cada vez mais necessário.

Questão - Para que serve o ensino de história?

Tabela 15: Sobre função do ensino de história

\begin{tabular}{|c|c|c|c|c|}
\hline RESPOSTAS & SEXO & $\%$ & GRADUANDOS & $\%$ \\
\hline \multirow{2}{*}{$\begin{array}{l}\text { Desenvolver um pensamento } \\
\text { crítico da realidade }\end{array}$} & 9 homens & $24,3(9 / 37)$ & \multirow[t]{2}{*}{32} & \multirow[t]{2}{*}{36} \\
\hline & 23 mulheres & $44,2(23 / 52)$ & & \\
\hline \multirow{2}{*}{$\begin{array}{lll}\begin{array}{l}\text { Construir } \\
\text { histórico }\end{array} & \text { o } & \text { pensamento } \\
\text { histo }\end{array}$} & 12 homens & $32,4(12 / 37)$ & \multirow[t]{2}{*}{24} & \multirow[t]{2}{*}{27} \\
\hline & 12 mulheres & $23,1(12 / 52)$ & & \\
\hline \multirow{2}{*}{$\begin{array}{l}\text { Relacionar passado, presente e } \\
\text { futuro }\end{array}$} & 9 homens & $24,3(9 / 37)$ & \multirow[t]{2}{*}{18} & \multirow[t]{2}{*}{20,2} \\
\hline & 9 mulheres & $17,3(9 / 52)$ & & \\
\hline \multirow[t]{2}{*}{ Não sabe ou não respondeu } & 3 homens & $8,2(3 / 37)$ & \multirow[t]{2}{*}{10} & \multirow[t]{2}{*}{11,2} \\
\hline & 7 mulheres & $13,5(7 / 52)$ & & \\
\hline \multirow[t]{2}{*}{ Para ter conhecimento } & 4 homens & $10,8(4 / 37)$ & \multirow[t]{2}{*}{5} & \multirow[t]{2}{*}{5,6} \\
\hline & 1 mulher & $1,9(1 / 52)$ & & \\
\hline TOTAL & \multicolumn{4}{|c|}{89} \\
\hline
\end{tabular}

Fonte: Os autores.

Para esses futuros professores e professoras, o ensino de História ideal objetivaria "construir o pensamento histórico" $(24,7 \%)$ e faria "refletir sobre a realidade para nela 
intervir" (23,6\%). A "construção de cidadania", objetivo obrigatório na grande maioria dos currículos de História voltados para a escola básica, teve $20,2 \%$ de adeptos, ao passo que a promoção da "relação entre passado, presente e futuro" é ideal para 16,9\% dos educadores. Observa-se, portanto, que nesses futuros professores de História é mister construir uma relação entre a formação do pensamento histórico e sua fruição por meio de ações históricas conscientes - consciência histórica. Importante mencionar que para eles a ideia de um ensino de história neutro não lhes apetece (4,5\%), fato importante em um tempo de recrudescimento de narrativas históricas conservadoras que desejam amordaçar o ensino de História, retirando de si sua característica de promoção do poder de crítica.

\section{Questão - Qual seria o ensino de história ideal?}

Tabela 16 - Sobre a noção de um ensino de História ideal

\begin{tabular}{|c|c|c|c|c|}
\hline RESPOSTAS & SEXO & $\%$ & GRADUANDOS & $\%$ \\
\hline \multirow{2}{*}{$\begin{array}{lll}\begin{array}{l}\text { Construir } \\
\text { histórico }\end{array} & \text { o pensamento } \\
\end{array}$} & 6 homens & $16,2(6 / 37)$ & \multirow[t]{2}{*}{22} & \multirow[t]{2}{*}{24,7} \\
\hline & 16 mulheres & $30,8(16 / 52)$ & & \\
\hline \multirow{2}{*}{$\begin{array}{l}\text { O que faz refletir sobre a } \\
\text { realidade para nela intervir }\end{array}$} & 12 homens & $32,4(12 / 37)$ & \multirow[t]{2}{*}{21} & \multirow[t]{2}{*}{23,6} \\
\hline & 9 mulheres & $17,3(9 / 52)$ & & \\
\hline \multirow[t]{2}{*}{ Que construa a cidadania } & 9 homens & $24,3(9 / 37)$ & \multirow[t]{2}{*}{18} & \multirow[t]{2}{*}{20,2} \\
\hline & 9 mulheres & $17,3(9 / 52)$ & & \\
\hline \multirow{2}{*}{$\begin{array}{l}\text { Relacionar passado, presente e } \\
\text { futuro }\end{array}$} & 8 homens & $21,6(8 / 37)$ & \multirow[t]{2}{*}{15} & \multirow[t]{2}{*}{16,9} \\
\hline & 7 mulheres & $13,5(7 / 52)$ & & \\
\hline \multirow[t]{2}{*}{ Não sabe ou não respondeu } & 2 homens & $5,4(2 / 37)$ & \multirow[t]{2}{*}{4} & \multirow[t]{2}{*}{4,5} \\
\hline & 2 mulheres & $3,8(2 / 52)$ & & \\
\hline \multirow[t]{2}{*}{ Que fosse neutro } & 3 homens & $8,1(3 / 37)$ & \multirow[t]{2}{*}{4} & \multirow[t]{2}{*}{4,5} \\
\hline & 1 mulher & $1,9(1 / 52)$ & & \\
\hline \multirow{2}{*}{$\begin{array}{lcr}\text { Com a } & \text { articulação entre } \\
\text { conceitos } & \text { substantivos } & \text { e } \\
\text { conceitos de segunda ordem }\end{array}$} & 2 homens & $5,4(2 / 37)$ & \multirow[t]{2}{*}{4} & \multirow[t]{2}{*}{4,5} \\
\hline & 2 mulheres & $3,8(2 / 52)$ & & \\
\hline Não usar livro didático & 1 homem & $2,7(1 / 37)$ & 1 & 1,1 \\
\hline TOTAL & \multicolumn{4}{|l|}{89} \\
\hline
\end{tabular}

Fonte: Os autores.

Há que se observar, no entanto, a dificuldade dos participantes do grupo pesquisado em tornar o discurso acima mencionado em ações práticas no espaço da sala de aula. Tal constatação se deve a fato de os professores não apresentarem, dentre as possibilidades, uma predominante que caracterize o conteúdo principal a ser ministrado nas aulas de História. Esse conteúdo é pulverizado em vários itens, desde os mais técnicos, referenciados na Educação Histórica, como é o caso da "articulação entre os conceitos substantivos e os conceitos de segunda ordem" (20,2\%); passando por conteúdos relacionados à vivência histórica cotidiana, tais como "Se orientar no tempo para prospectar o futuro" (18\%), 
"Parâmetros para agir na sociedade de forma crítica e consciente" (15,7\%), "Relacionar passado, presente e futuro" (10,1\%); ou inerentes à individualidade do estudante - "Assuntos relacionados ao seu interesse" (13,5\%); ou ainda, enfim, às questões gera is da formação da cognição histórica dos alunos - "Construir o pensamento histórico" (13,5\%).

Questão - O que os alunos devem aprender em História?

Tabela 17 - Sobre o que o Ensino Médio deve aprender em História

\begin{tabular}{|c|c|c|c|c|}
\hline $\begin{array}{l}\text { RESPOSTAS } \\
\end{array}$ & SEXO & $\%$ & GRADUANDOS & $\%$ \\
\hline \multirow{2}{*}{$\begin{array}{l}\text { Articulação entre os substantivos e } \\
\text { conceitos de segunda ordem }\end{array}$} & 10 homens & $27(10 / 37)$ & \multirow[t]{2}{*}{18} & \multirow[t]{2}{*}{20,2} \\
\hline & 8 mulheres & $15,4(8 / 52)$ & & \\
\hline \multirow{2}{*}{$\begin{array}{llll}\text { Se orientar no tempo para } \\
\text { prospectivar o futuro }\end{array}$} & 4 homens & $10,8(4 / 37)$ & \multirow[t]{2}{*}{16} & \multirow[t]{2}{*}{18} \\
\hline & 12 mulheres & $23,1(12 / 52)$ & & \\
\hline \multirow{2}{*}{$\begin{array}{l}\text { Parâmetros para agir na sociedade de } \\
\text { forma crítica e consciente }\end{array}$} & 5 homens & $13,5(5 / 37)$ & \multirow[t]{2}{*}{14} & \multirow[t]{2}{*}{15,7} \\
\hline & 9 mulheres & $17,3(9 / 52)$ & & \\
\hline \multirow[t]{2}{*}{ Construir o pensamento histórico } & 6 homens & $16,2(6 / 37)$ & \multirow[t]{2}{*}{12} & \multirow[t]{2}{*}{13,5} \\
\hline & 6 mulheres & $11,5(6 / 52)$ & & \\
\hline \multirow{2}{*}{$\begin{array}{llll}\begin{array}{l}\text { Assuntos } \\
\text { interesse }\end{array} & \text { relacionados } & \text { ao } & \text { seu } \\
\end{array}$} & 4 homens & $10,8(4 / 37)$ & \multirow[t]{2}{*}{12} & \multirow[t]{2}{*}{13,5} \\
\hline & 8 mulheres & $15,4(8 / 52)$ & & \\
\hline \multirow[t]{2}{*}{ Relacionar passado, presente e futuro } & 4 homens & $10,8(4 / 37)$ & \multirow[t]{2}{*}{9} & \multirow[t]{2}{*}{10,1} \\
\hline & 5 mulheres & $9,6(5 / 52)$ & & \\
\hline \multirow[t]{2}{*}{ Não sabe ou não respondeu } & 3 homens & $8,1(3 / 37)$ & \multirow[t]{2}{*}{7} & \multirow[t]{2}{*}{7,9} \\
\hline & 4 mulheres & $7,7(4 / 52)$ & & \\
\hline $\begin{array}{l}\text { Parâmetros para modernização do } \\
\text { país }\end{array}$ & 1 homem & $2,8(1 / 37)$ & 1 & 1,1 \\
\hline TOTAL & 89 & & & \\
\hline
\end{tabular}

Fonte: Os autores.

Ao analisar as representações dos futuros professores a respeito do Ensino de História compreende-se que claramente entendem a importância entre a formação do pensamento histórico e o desenvolvimento de ações, refletidas historicamente, com a finalidade de orientar-se nos desafios conjunturais e estruturais do tempo - consciência histórica. Entretanto, ao sair dessa visão geral, estruturada, da relação entre formação e consciência históricas, os futuros professores revelam dificuldade em citar conteúdos que demonstrarão, praticamente, no cotidiano vivido, tal relação.

Mas... e para os estudantes secundaristas? Qual a importância do ensino de História para eles? Em que medida as representações constituídas pelos futuros professores se cotejadas com aquelas oriundas dos estudantes, se aproximarão ou serão distantes? 


\section{Representações sobre a Aprendizagem e o Ensino de História para os estudantes secundaristas}

Antes de estudar as representações dos estudantes a respeito do ensino de História, convém verificar a relação que os estudantes do Ensino Médio pesquisados têm com a escola. Para eles predomina a ideia de que a escola é importante "para o futuro profissional" (49,8\%; sendo $54,4 \%$ dos homens e $44,4 \%$ das mulheres). Além da questão econômica, centrada em uma escola importante para se constituir uma profissão, os secundaristas pesquisados citaram uma concepção ligada à escola como espaço de compreensão racional do cotidiano enfrentado - "para entender a realidade" (23,8\%). Finalmente, a questão da sociabilidade existente na escola a torna importante para $20,3 \%$ dos estudantes - "para se fazer amigos" $(23,7 \%$ das mulheres e $17,3 \%$ dos homens).

Questão - Qual seria a importância da escola?

Tabela 18 - Sobre importância da escola

\begin{tabular}{|l|c|c|c|c|}
\hline \multicolumn{1}{|c|}{ RESPOSTAS } & SEXO & $\%$ & ALUNOS & $\%$ \\
\hline Para o futuro profissional & 123 homens & $54,4(123 / 226)$ & 211 & 49,8 \\
\cline { 2 - 3 } & 88 mulheres & $44,4(88 / 198)$ & & \\
\hline Para entender a realidade & 56 homens & $24,8(56 / 226)$ & 101 & 23,8 \\
\cline { 2 - 3 } & 45 mulheres & $22,7(45 / 198)$ & & \\
\hline Para se fazer amigos & 39 homens & $17,3(39 / 226)$ & 86 & 20,3 \\
\cline { 2 - 3 } & 47 mulheres & $23,7(47 / 198)$ & & \multirow{2}{*}{26} \\
\hline Para a vida prática & 8 homens & $3,5(8 / 226)$ & & \\
\cline { 2 - 3 } & 18 mulheres & $9,2(18 / 198)$ & & \\
\hline TOTAL & 424 & & \\
\hline
\end{tabular}

No que concerne à compreensão que têm da História, os estudantes apresentam uma visão factual, pois para eles a História é constituída por "fatos que ocorreram no passado" $(39,6 \%)$ ou "os grandes acontecimentos junto com o cotidiano das pessoas" (35,6\%). Tais visões, abarcam três em cada quatro estudantes do grupo pesquisado nos quatro anos de duração da pesquisa $(75,2 \%)$, sendo $77,9 \%$ dos homens $(44,7+33,2 \%)$ e $72,2 \%$ das mulheres $(33,8 \%+38,4 \%)$. Somente $21,9 \%$ dos pesquisados relacionam a História com aspectos de orientação temporal e/ou de construção de identidade ("Serve para entender o presente e o que somos" - 12,7\%; "Entender o passado, para agir no presente e fazer o futuro" - 9,2\%). Dados que representam uma visão tradicional que compreende a História como uma coleção de fatos encadeados e sucessivos no tempo. 


\section{Questão - O que é história?}

Tabela 19 - Sobre o que seria a História

\begin{tabular}{|c|c|c|c|c|}
\hline RESPOSTAS & SEXO & $\%$ & ALUNOS & $\%$ \\
\hline \multirow{2}{*}{$\begin{array}{l}\text { Os fatos que ocorreram no } \\
\text { passado }\end{array}$} & 101 homens & $44,7(101 / 226)$ & \multirow{2}{*}{168} & \multirow[t]{2}{*}{39,6} \\
\hline & 67 mulheres & $33,8(67 / 198)$ & & \\
\hline \multirow{2}{*}{$\begin{array}{l}\text { Os grandes a contecimentos junto } \\
\text { com o cotidiano das pessoas }\end{array}$} & 75 homens & $33,2(75 / 226)$ & \multirow[t]{2}{*}{151} & \multirow[t]{2}{*}{35,6} \\
\hline & 76 mulheres & $38,4(76 / 198)$ & & \\
\hline \multirow{2}{*}{$\begin{array}{l}\text { Serve para entender o presente } \mathrm{e} \\
\text { o que somos }\end{array}$} & 24 homens & $10,6(24 / 226)$ & \multirow[t]{2}{*}{54} & \multirow[t]{2}{*}{12,7} \\
\hline & 30 mulheres & $15,2(30 / 198)$ & & \\
\hline \multirow{2}{*}{$\begin{array}{l}\text { Entender o passado, para agir no } \\
\text { presente e fazer o futuro }{ }^{16}\end{array}$} & 19 homens & $8,4(19 / 226)$ & \multirow[t]{2}{*}{39} & \multirow[t]{2}{*}{9,2} \\
\hline & 20 mulheres & $10,1(20 / 198)$ & & \\
\hline \multirow[t]{2}{*}{ Não respondeu ou não sabe } & 7 homens & $3,1(7 / 226)$ & \multirow[t]{2}{*}{12} & \multirow[t]{2}{*}{2,8} \\
\hline & 5 homens & $2,5(5 / 198)$ & & \\
\hline TOTAL & \multicolumn{4}{|c|}{424} \\
\hline
\end{tabular}

Fonte: Os autores.

Para a maioria dos estudantes do Ensino Médio pesquisados (37,8\%) a História tem como função apenas a compreensão a respeito do passado. Trata-se de uma visão que pensa a História como uma coleção de fatos no tempo, que integra a memória de pessoas e grupos como algo permanente. Está lá... faz parte da vida, das origens, precede a nossa geração, mas não mantém, necessariamente, vínculo com ela, pois, afinal de contas, "não vivemos aquela época" - dizem muitos desses alunos.

Questão - Para que serve o ensino de história?

Tabela 20 - Sobre função do ensino de história para o EM

\begin{tabular}{|c|c|c|c|c|}
\hline RESPOSTAS & SEXO & $\%$ & ALUNOS & $\%$ \\
\hline \multirow[t]{2}{*}{ Para entender o passado } & 92 homens & 40,8 & \multirow[t]{2}{*}{160} & \multirow[t]{2}{*}{37,8} \\
\hline & 68 mulheres & 34,4 & & \\
\hline \multirow{2}{*}{$\begin{array}{l}\text { Para entender o passado, para agir } \\
\text { no presente e fazer o futuro }\end{array}$} & 48 homens & 21,2 & \multirow[t]{2}{*}{86} & \multirow[t]{2}{*}{20,3} \\
\hline & 38 mulheres & 19,3 & & \\
\hline \multirow[t]{2}{*}{ Para relacionar com o presente } & 41 homens & 18,1 & \multirow[t]{2}{*}{85} & \multirow[t]{2}{*}{20} \\
\hline & 44 mulheres & 22,2 & & \\
\hline \multirow[t]{2}{*}{ Para ter conhecimentos } & 14 homens & 6,2 & \multirow[t]{2}{*}{40} & \multirow[t]{2}{*}{9,4} \\
\hline & 28 mulheres & 14,1 & & \\
\hline \multirow[t]{2}{*}{ Não respondeu ou não sabe } & 10 homens & 4,4 & \multirow[t]{2}{*}{18} & \multirow[t]{2}{*}{4,2} \\
\hline & 8 mulheres & 4 & & \\
\hline \multirow[t]{2}{*}{ Para nada } & 16 homens & 7,1 & \multirow[t]{2}{*}{25} & \multirow[t]{2}{*}{5,9} \\
\hline & 9 mulheres & 4,5 & & \\
\hline \multirow[t]{2}{*}{ Para saber a origem das coisas } & 5 homens & 2,2 & \multirow[t]{2}{*}{10} & \multirow[t]{2}{*}{2,4} \\
\hline & 3 mulheres & 1,5 & & \\
\hline TOTAL & \multicolumn{4}{|c|}{424} \\
\hline
\end{tabular}

Fonte: Os autores.

16 Logo na estrada do prédio escolar, encontra-se abaixo do logotipo do colégio em letras grandes a frase do aluno Guilherme Mendes Souza: “Revendo o passado, cuidando do presente, construindo o futuro", o que pode ter influenciado as respostas. 
O estudo da História é importante para relacionar passado e presente para $20 \%$ dos estudantes. Embora o passado continue a apresentar-se como coleção de fatos no tempo, tem a função de, em ligação com o presente, trazer consigo um modelo de orientação a seguir. As experiências temporais são dotadas de sentido e tornam-se modelos de orientação para as novas gerações em seu cotidiano. Reproduzir a experiência, independentemente dos aspectos de historicidade, se constitui como regra, pois se tais ações já foram vivenciadas com êxito, porque não podem nortear a geração atual? A História é, portanto, "mestra da vida". ${ }^{17}$

Para um grupo expressivo de estudantes do Ensino Médio (20,3\%), a História tem como função a articulação das diferentes temporalidades. Passado, presente e futuro se relacionam em experiências individuais e coletivas, pois a carga de historicidade subsumida às ações são consideradas pelos estudantes. Para estes já não se mostra suficiente uma História fornecedora de tradições a serem eternizadas temporalmente como sentido à orientação de pessoas e da sociedade. Tampouco uma História que busca exemplos a serem transpostos a historicamente para todos. Sob a égide da racionalidade histórica, a História é vista como uma ciência que politiza. Desperta no estudante um raciocínio que lhe permite relacionar fatos colecionados no tempo em sua própria historicidade, com as mudanças e permanências inerentes ao presente histórico dos indivíduos. Mais... abre espaço para a reflexão acerca do que advirá.

Questão - O que falta para um ensino de história melhor?

Tabela 21 - Sobre condição para melhorar o ensino de história

\begin{tabular}{|c|c|c|c|c|}
\hline RESPOSTAS & SEXO & $\%$ & ALUNOS & $\%$ \\
\hline \multirow[t]{2}{*}{ Mais recursos didáticos } & 84 homens & 37,2 & \multirow[t]{2}{*}{134} & \multirow[t]{2}{*}{31,6} \\
\hline & 50 mulheres & 25,2 & & \\
\hline \multirow[t]{2}{*}{ Mais estudo por parte dos alunos } & 56 homens & 24,8 & \multirow[t]{2}{*}{114} & \multirow[t]{2}{*}{26,9} \\
\hline & 58 mulheres & 29,3 & & \\
\hline \multirow{2}{*}{$\begin{array}{l}\text { Mais disciplina por parte dos } \\
\text { alunos }\end{array}$} & 38 homens & 16,8 & \multirow[t]{2}{*}{77} & \multirow[t]{2}{*}{18,2} \\
\hline & 39 mulheres & 19,7 & & \\
\hline \multirow[t]{2}{*}{ Usar o livro didático ${ }^{18}$} & 20 homens & 8,8 & \multirow[t]{2}{*}{54} & \multirow[t]{2}{*}{12,7} \\
\hline & 34 mulheres & 17,2 & & \\
\hline \multirow[t]{2}{*}{ Não respondeu ou não sabe } & 14 homens & 6,2 & \multirow[t]{2}{*}{24} & \multirow[t]{2}{*}{5,7} \\
\hline & 10 mulheres & 5,1 & & \\
\hline \multirow[t]{2}{*}{ Nada, está bom assim } & 7 homens & 3,1 & \multirow[t]{2}{*}{11} & \multirow[t]{2}{*}{2,6} \\
\hline & 4 mulheres & 2,0 & & \\
\hline \multirow[t]{2}{*}{ Professora ser mais paciente } & 6 homens & 2,7 & \multirow[t]{2}{*}{9} & \multirow[t]{2}{*}{2,1} \\
\hline & 3 mulheres & 1,5 & & \\
\hline Não sabe ou não respondeu & 1 homem & 0,4 & 1 & 0,2 \\
\hline TOTAL & \multicolumn{4}{|c|}{424} \\
\hline
\end{tabular}

Fonte: Os autores.

17 Ver nota 13.

18 Embora exista um número significativo de livros didáticos de história na escola, estes não são usados pela professora, que prefere elaborar seu próprio material didático. 
Embora a falta de recursos didáticos tenha sido apontada pelos alunos como o principal motivo pela falta de um estudo melhorado da História na sala de aula $(31,6 \%)$, claro está que os estudantes pesquisados entendem ser os maiores responsáveis pelas dificuldades para a qualificação da aprendizagem histórica na sala de aula, seja pelo seu desinteresse nos estudos (26,9\%), seja por questões de indisciplina (18,2\%). A mencionar que as mulheres compreendem as limitações ao ensino devido à imposição desses fatores em maior grau que os homens (29,3\% e 19,7\%, respectivamente). Dados que coadunam com a maior preocupação, também pelas mulheres, pelo não uso dos livros didáticos nas aulas de História, se comparados aos estudantes homens (17,2\% e $8,8 \%$, respectivamente). Não foi imputado aos professores, por parte desse grande grupo, a dificuldade no ensino da História em sala de aula, fator que destoa das narrativas comumente ouvidas nos meios de comunicação que procuram reservar (injustamente), ao professor, boa parte dos problemas existentes no sistema educacional.

\section{Considerações Finais}

Ficou evidenciado que, logo na elaboração do instrumento de investigação, os pesquisadores tendiam a não se dar conta de seus próprios pré-saberes ou representações sobre quem eram esses alunos do Ensino Médio, e, sobre o que estes sabiam de História. Fixados em uma imagem típica e essencialista de adolescente, a despeito de que a infância e a adolescência são construções histórico-culturais, a inquietude, a curiosidade, a impulsividade, a energia, a necessidade de explorar, ou mesmo de quebrar regras e normas, são características que costumam não ser entendidas como "expressão e produto da era em que vivemos", e este "adolescente" hiperativo não é visto como "protagonista de um tempo/espaço cada vez mais fluído, instável, matizado, rápido e desconcertante" (COSTA, 2008, p. 274).

Habituados a interferir como "coautores" nos textos hipermidiáticos, realizando comentários, jogando, construindo, elaborando, respondendo, interagindo, os alunos do Ensino Médio produzem uma forma de conhecer dissonante com o modelo escolar posto e com o que em geral os graduandos futuros docentes esperam encontrar conforme suas representações do que seria o "aluno adolescente". Sancristán argumenta que os adultos definem a si mesmos, e os jovens são definidos pelos adultos: "se eles não falam, e nós adultos fazemos isso por eles, é lógico que a explicação de sua experiência seja muito intermediada pelas visões que temos deles" (SANCRISTÁN, 2005, p.12). É construída uma definição sobre o "aluno adolescente" que orienta nossos comportamentos, práticas e percepções em relação a este "Outro", sem que se infira que o movimento poderia ser inverso, isto é, partir das 
condições, saberes e perspectivas deste "Outro" para possibilitar a reflexão sobre os processos de ensino (SANCRISTÁN, 2005, p. 18).

$\mathrm{Na}$ atualidade, torna-se problemático determinar/situar o "adolescente" conforme a faixa etária na articulação com certos valores e comportamentos. Em especial quando se define o acesso à fase adulta conforme a inserção no mercado de trabalho, a constituição de uma nova unidade familiar e a saída da casa paterna, já que tais fatores vêm acontecendo cada vez mais cedo para a classe social mais baixa e cada vez mais tarde para uma classe social mais alta, e ainda: não se configuram etapas lineares, mas com idas e vindas frequentes (SPOSITO, 2005, p.91). Vale dizer que, diferente dos estudantes universitários (todos do curso de história matutino), muitos alunos do Ensino Médio (noturno) tinham cumprido pelo menos uma destas "etapas", o que, de certo, resultava no que se entende por "descronologização" ou "desregulação" da "adolescência" (SPOSITO, 2005, p.90-91).

Maria Rita Kehl (2004, p. 91) considera esta "descronologização", mas destaca que o período da "adolescência" vem se dilatando, independente da classe social, devido a os fatores como aumento do período de formação escolar, alta competitividade do mercado de trabalho, escassez de empregos, que "obrigam o jovem adulto a viver cada vez mais tempo na condição de 'adolescente', dependente da família, apartado das decisões e responsabilidades da vida pública, incapaz de decidir seu destino”.

Ao se cotejar as representações dos graduandos futuros professores e dos estudantes de Ensino Médio a respeito da História, verifica-se que as representações que o primeiro grupo tem a respeito do segundo grupo, não coadunam com o que os estudantes secundaristas pensam de si mesmos e de sua relação com o mundo.

Para os graduandos, os estudantes secundaristas não se importam com a escola e a política, tampouco com o estudo da História. Embora sejam grupos com pequena diferença de idade entre si, o espaço da sala de aula gera uma espécie de "síndrome do pânico" aos futuros professores que haviam passado há pouco tempo, por este mesmo lugar, como estudantes secundaristas. Os próprios estudantes do Ensino Médio admitem que grande parte da dificuldade de aprendizagem existente na escola, atualmente, deve-se à sua relação indisciplinada com este espaço.

Há, aqui, um desafio grande ao espaço escolar, pois ao cotejar-se as representações dos grupos pesquisados no que concerne à relação com o futuro, ambos compreendem ser o trabalho determinante para a ascendência à condição adulta, à emancipação. Os estudos representam parte importante desse processo, pois ele é caminho para o trabalho melhor qualificado, inclusive derivado do âmbito universitário. Embora seja imputada aos secundaristas, por parte dos jovens graduandos, a pecha de despolitização, verifica-se que os adolescentes estudantes do Ensino Médio se compreendem como agentes de mudança, protagonistas. 
Mas tal protagonismo demonstra-se limitado às ações políticas no âmbito das relações humanas, no campo da ética relacional, no respeito à diversidade, à alteridade. Talvisão pode estar relacionada, de alguma forma, à importância dada à religiosida de por boa parte do grupo. Ações politizadas que demonstram maior relação com o coletivo, com o público, como a preocupação com a justiça social ou com o meio ambiente, não estão no escopo desse grupo.

Nesse sentido, as narrativas apresentadas relacionadas aos estudos da História, demonstram a necessidade do avanço do trabalho com os estudantes a partir da perspectiva da construção e desenvolvimento de consciência histórica no âmbito escolar. Se de um lado os futuros docentes compreendem a importância do a prendizado histórico para a construção do pensamento histórico, bem como de uma visão crítica e cidadã a respeito de seu tempo para nele intervir, do outro os estudantes entendem, majoritariamente, que o estudo da História se volta apenas para o passado, fator que remete a uma visão tradicional da História, ou como fornecedoras de modelos culturais a serem reproduzidos. Há, porém, um número crescente de estudantes que relacionam o estudo da História com seu próprio tempo e, até mesmo, com o futuro, sugerindo que um trabalho em sala de aula, voltado para a aprendizagem histórica na perspectiva da Didática da História, pode contribuir para o desenvolvimento do poder crítico, bem como com a construção de narrativas históricas potentes que considerem a perspectivação do pensamento, a historicidade, a dimensão autoral, com vistas à profícua relação da História com sua própria vida e com a sociedade em que vive.

\section{Referências}

ALVES, Ronaldo Cardoso. Da Consciência Histórica (Pré) (Pós?) Moderna: reflexões a partir do pensamento de Reinhart Koselleck. Saeculum, João Pessoa, v. 30, p. 321-339, 2014a.

A aula de História como lugar do ensino, da pesquisa e da extensão. Espaço Pedagógico, Passo Fundo, v. 21, p. 274-287, 2014b.

A transferência da família real portuguesa para o Brasil: explicação histórica em estudantes brasileiros e portugueses. Antíteses, Londrina, v. 5, n. 10, p. 691-716, 2013.

ANDRÉ, Marli E. D. Etnografia da prática escolar. Campinas: Papirus, 1995.

COSTA, Marisa Vorraber. Cartografando a gurizada da fronteira: novas subjetividades na escola.In: ALBUQUERQUE JUNIOR, Durval Muniz de; VEIGA-NETO, Alfredo; SOUZA FILHO, Alípio. (Org.). Cartografias de Foucault. Belo Horizonte: Autêntica, 2008. p. 269-294. 
DUVEEN, Gerard. O Poder das Idéias. In: MOSCOVICI, Serge. Representações Sociais: investigações em psicologia social. 3. ed. Petrópolis: Vozes, 2003. p.7-28.

EZPELETA, Justa; ROCKWELL, Elsie. Pesquisa Participante. São Paulo: Cortez: Autores Associados, 1989.

GEERTZ, Clifford. A Interpretação das Culturas. Rio de Janeiro: LTC, 2012.

KEHL, Maria Rita. A juventude como sintoma da cultura. In NOVAES, Regina;VARINNUCHI, Paulo (Org.). Juventude e sociedade: trabalho, educação, cultura e participação. 2. ed. São Paulo: Editora Fundação Perseu Abramo, 2004.

KOSELLECK, Reinhart. Futuro Passado: contribuição à semântica dos tempos históricos. Tradução Wilma Patrícia Maas e Carlos Almeida Pereira. Rio de Janeiro: Contraponto \& Ed. PUC-Rio, 2006.

LEE, Peter. Progressão da compreensão dos alunos em história In: JORNADAS INTERNACIONAIS DE EDUCAÇÃO HISTÓRICA, 2001, Braga, Portugal. Atas... Braga, 2001.

MOSCOVICI, Serge. Das Representações Coletivas às Representações Sociais: elementos para uma história. In. JODELET, Denise (Org.). As Representações Sociais. Rio de Janeiro: EdUERJ, 2001.

PESAVENTO, Sandra Jatahy. História \& História Cultural. Belo Horizonte: Autêntica, 2003.

RÜSEN, Jörn. O desenvolvimento da competência narrativa na aprendizagem histórica: uma hipótese ontogenética relativa à consciência moral. Tradução Ana Claudia Urban e Flávia Vanessa Starcke. In. BARCA, Isabel; MARTINS, Estevão de Rezende; SCHMIDT, Maria Auxiliadora (Org.). Jörn Rüsen e o ensino de História. Curitiba: Editora UFPR, 2010. p. 51- 77.

SACRISTÁN, José Gimeno. $O$ aluno como invenção. Trad. Daisy Vaz de Moraes. Porto Alegre: Artmed, 2005.

SPOSITO, M. P. Algumas reflexões e muitas indagações sobre as relações entre a juventude e escola no Brasil. In ABRAMO, H. W.; BRANCO, P. P. M. (Org.). Retratos da juventude brasileira. Análises de uma pesquisa nacional. São Paulo: Instituto Cidadania/Editora Fundação Perseu Abramo, 2005.

VENTURINI, G. Introdução metodológica. In ABRAMO, H. W.; BRANCO, P. P. M. (Org.). Retratos da juventude brasileira. Análises de uma pesquisa nacional. São Paulo: Instituto Cidadania/ Editora Fundação Perseu Abramo, 2005.

Recebido em 28.09.2016 - Aprovado em 30.11.2016 